\title{
Management, regulation and environmental impacts of nitrogen fertilization in northwestern Europe under the Nitrates Directive; a benchmark study
}

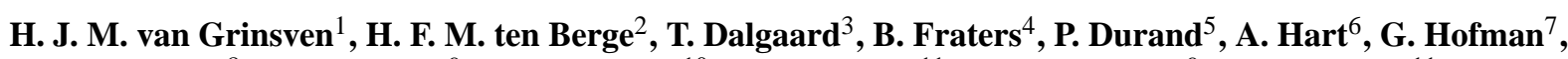 \\ B. H. Jacobsen ${ }^{8}$, S. T. J. Lalor ${ }^{9}$, J. P. Lesschen ${ }^{10}$, B. Osterburg ${ }^{11}$, K. G. Richards ${ }^{9}$, A.-K. Techen ${ }^{11}$, F. Vertès ${ }^{5}$, \\ J. Webb ${ }^{12}$, and W. J. Willems ${ }^{1}$ \\ ${ }^{1}$ PBL Netherlands Environmental Assessment Agency, Department: Water, Agriculture and Food, Bilthoven, The Netherlands \\ ${ }^{2}$ Plant Research International, Wageningen University and Research Centre, The Netherlands \\ ${ }^{3}$ Aarhus University, Department of Agroecology, Foulum, Denmark \\ ${ }^{4}$ National Institute for Public Health and the Environment, Bilthoven, The Netherlands \\ ${ }^{5}$ INRA, UMR1069, Sol Agro and Hydrosysteme, 35000 Rennes, France \\ ${ }^{6}$ Environmental Agency, Olton, UK \\ ${ }^{7}$ Ghent University, Department of Soil Management, Belgium \\ ${ }^{8}$ Institute of Food and Resource Economics, University of Copenhagen, Denmark \\ ${ }^{9}$ Teagasc, Crops Environment and Land Use Programme, Johnstown Castle, Wexford, Ireland \\ ${ }^{10}$ Alterra, Wageningen University and Research Centre, The Netherlands \\ ${ }^{11}$ Institute of Rural Studies, Johann Heinrich von Thünen-Institut (vTI), Bundesforschungsinstitut für Ländliche Räume, \\ Wald und Fischerei, Germany \\ ${ }^{12}$ AEA Energy and Environment, Didcot, UK
}

Correspondence to: H. J. M. van Grinsven (hans.vangrinsven@pbl.nl)

Received: 21 May 2012 - Published in Biogeosciences Discuss.: 22 June 2012

Revised: 16 November 2012 - Accepted: 19 November 2012 - Published: 14 December 2012

\begin{abstract}
Implementation of the Nitrates Directive (NiD) and its environmental impacts were compared for member states in the northwest of the European Union (Ireland, United Kingdom, Denmark, the Netherlands, Belgium, Northern France and Germany). The main sources of data were national reports for the third reporting period for the NiD (2004-2007) and results of the MITERRA-EUROPE model. Implementation of the NiD in the considered member states is fairly comparable regarding restrictions for where and when to apply fertilizer and manure, but very different regarding application limits for $\mathrm{N}$ fertilization. Issues of concern and improvement of the implementation of the NiD are accounting for the fertilizer value of nitrogen in manure, and relating application limits for total nitrogen $(\mathrm{N})$ to potential crop yield and $\mathrm{N}$ removal. The most significant environmental effect of the implementation of the NiD since 1995 is a major contribution to the decrease of the soil $\mathrm{N}$ balance
\end{abstract}

(N surplus), particularly in Belgium, Denmark, Ireland, the Netherlands and the United Kingdom. This decrease is accompanied by a modest decrease of nitrate concentrations since 2000 in fresh surface waters in most countries. This decrease is less prominent for groundwater in view of delayed response of nitrate in deep aquifers. In spite of improved fertilization practices, the southeast of the Netherlands, the Flemish Region and Brittany remain to be regions of major concern in view of a combination of a high nitrogen surplus, high leaching fractions to groundwater and tenacious exceedance of the water quality standards. On average the gross $\mathrm{N}$ balance in 2008 for the seven member states in EUROSTAT and in national reports was about $20 \mathrm{~kg} \mathrm{~N} \mathrm{ha}^{-1} \mathrm{yr}^{-1}$ lower than by MITERRA. The major cause is higher estimates of $\mathrm{N}$ removal in national reports which can amount to more than $50 \mathrm{~kg} \mathrm{Nha}^{-1} \mathrm{yr}^{-1}$. Differences between procedures in member states to assess nitrogen balances and water 
quality and a lack of cross-boundary policy evaluations are handicaps when benchmarking the effectiveness of the NiD. This provides a challenge for the European Commission and its member states, as the NiD remains an important piece of legislation for protecting drinking water quality in regions with many private or small public production facilities and controlling aquatic eutrophication from agricultural sources.

\section{Introduction}

The main aim of the Nitrates Directive (1991: Directive 91/676/EEC; hereafter referred to as NiD) is to reduce water pollution caused or induced by nitrate and phosphorus from agricultural sources. The NiD is the most important piece of European (EU) regulation for reducing environmental impacts of fertilizer and manure and for increasing nitrogen use efficiency. The gross nitrogen balance, or nitrogen surplus, (Schröder et al., 2004; Vries et al., 2011) is an important indicator to evaluate the environmental impacts of the Nitrates Directive, particularly for the water compartment. This makes the NiD an important supporting instrument for other EU directives i.e. the Drinking Water Framework Directive (98/83/EC), the Water Frame Directive (2000/60/EC) and the Marine Strategy Framework Directive (2008/56/EC). The NiD legally restricts annual farm application of manure to $170 \mathrm{~kg} \mathrm{ha}^{-1}$ of nitrogen, or in case of derogation to inputs up to $250 \mathrm{~kg} \mathrm{ha}^{-1}$ (Oenema, 2004). The tenacious problem of regional nitrogen (and phosphorus) surpluses can be resolved by manure transport to other regions and by manure processing. In the case of the Netherlands and the Flemish region, part of the (processed) manure is exported to other countries.

Agricultural practices in general, and more specifically application rates and management of chemical fertilizers and animal manures, vary greatly between and within EU member states. This makes it interesting to compare nitrogen management and regulation between countries and relate this to the observed states and trends of nitrate concentrations in groundwater and surface water. Since the introduction of the NiD in 1991, EU member states have implemented several action programs and have delivered several monitoring reports. The EU Commission obliges member states to report on the results of these action programs. It also charged synthesizing studies on these national reports but these reports are not publicly available. However, the EU Commission did publish summaries of the national data and reports in 2007 and 2011. In addition, Fraters et al. (2011) evaluated the effectiveness of environmental monitoring programs for the $\mathrm{NiD}$. However, overall insight into the effectiveness of the $\mathrm{NiD}$ in the EU is still limited and rarely published in peerreviewed journals. Together with the submission of the next set of national monitoring reports for the NiD, this paper could increase this insight and help to improve implementation of the NiD across the EU.
The combination of environmental directives and the Common Agricultural Policy should provide food security and a healthy natural environment in Europe while maintaining a level playing field for the agricultural entrepreneurs (De Clercq et al., 2001). This is particularly true for agriculture in northwestern EU member states as they compete to provide food to consumers in the so-called "London-Berlin-Paris triangle".

The purpose of this paper is to compare, evaluate and benchmark the implementation of the Nitrates Directive in the northwestern member states of the EU. The objective is to relate differences in implementation to differences in structure, intensity and practices of the agricultural sector and to sensitivity of soil water systems to nitrate pollution. Key issues of the NiD addressed in the benchmark are application rates of $\mathrm{N}$ in manure, the balance between applied $\mathrm{N}$ and crop requirements and water quality in relation to the nitrate target of $50 \mathrm{mg} \mathrm{NO}_{3}^{-} \mathrm{L}^{-1}$. The comparison is restricted to Denmark, Germany, the Netherlands, Belgium, the United Kingdom, Ireland and the northern part of France. Crop and fodder production potential per hectare on comparable soils in these countries are similar. Note however, that within the United Kingdom there are four separate governments and in Belgium two, which implement the Nitrates Directive in differing ways. Moreover, all these countries have regions with high livestock densities, causing feed requirements to exceed regional feed production, and manure production to exceed regional crop demands.

\section{Materials and methods}

\subsection{Data sources}

This analysis combines various existing studies on implementation of the Nitrates Directive (van Dijk and Berge, 2009; ten Berge and Dijk, 2009), gross nitrogen balances from Eurostat (2012), monitored nitrate concentrations in groundwater and surface water in synthesizing reports (European Commission, 2007, 2011; Fraters et al., 2011) and various national reports on implementation and evaluation of the Nitrates Directive for the last reporting period (Anonymous, 2008a, b, c, d; Desimpelaere et al., 2008; Zwart et al., 2008). A complication when comparing water quality data among EU member states (and sometimes within a single member state) to evaluate the NiD are the large differences in monitoring procedures, e.g. with regard to sampling density (Table 1), monitoring frequency and groundwater sampling depth (Fraters et al., 2011; European Commission, 2011), and data and procedures for calculation of nitrogen balances (Panten et al., 2009). In 2007 the total number of sampling sites for groundwater was 31000 and for surface water 27000 . 
Table 1. Density of groundwater and surface water sampling for the whole land surface in monitoring programs for the NiD (European Commission, 2011).

\begin{tabular}{lcc}
\hline & $\begin{array}{c}\text { Density of groundwater } \\
\text { sampling stations } \\
\text { (points/1000 } \mathrm{km}^{2} \text { ) }\end{array}$ & $\begin{array}{c}\text { Density of surface } \\
\text { water sampling stations } \\
\left.\text { (points } / 1000 \mathrm{~km}^{2}\right)\end{array}$ \\
\hline Belgium & 99 & 38 \\
Germany & 3 & 1 \\
Denmark & 34 & 5 \\
France & 5 & 3 \\
Ireland & 1 & 3 \\
Netherlands & 33 & 13 \\
United Kingdom & 13 & 33 \\
\hline
\end{tabular}

\subsection{Nitrogen balance}

In this study, calculation of the gross nitrogen balance (GNB) was based on the OECD method (OECD, 2007). In addition the soil $\mathrm{N}$ balance (SNB) is used which sometimes is confused with the soil surface N balance (SSNB). The GNB represents the total potential loading of nitrogen from primary agricultural production to the environment, but excluding $\mathrm{N}$ emissions from fossil fuel combustion for energy requirements for e.g. fertilizer manufacturing, housing, transport and soil and crop management and correcting for export and processing of manure. SNB or soil N surplus represents the total potential loading from nitrogen use on agricultural soil, while SSNB represents the total net nitrogen loading to the soil and water compartment.

GNB: fertilizer + manure production + other inputs net manure export - crop removal

SNB: GNB - N-loss housing - N-loss storage

SSNB: SNB - N-loss manure application

Other inputs include $\mathrm{N}$ deposition and biological $\mathrm{N}$ fixation (BNF), where $\mathrm{N}$ deposition is the result of $\mathrm{NH}_{3}$ and $\mathrm{NO}_{\mathrm{x}}$ emissions from both agricultural and other sources, mainly transportation and energy generation. Choosing one of the balance indicators for monitoring and evaluation of $\mathrm{NiD}$ effects is determined mainly by data availability. Data requirements for GNB are lowest, but GNB does not correct for environmental measures reducing ammonia emission following from other EU directives like the National Emission Ceilings (NEC) directive (2001/81/EC) and the Integrated Pollution Prevention (IPPC) directive (96/61/EC). However, different calculation procedures, particularly for determining manure input and nitrogen removal by crops, and also inclusion or exclusion of $\mathrm{N}$-losses during housing and storage (difference between gross and net soil balance) and of smaller input items, may need to be taken into account when comparing national or regional nitrogen balances.

For this reason the use of a model for determining the nitrogen balance is an additional valuable tool to evaluate the effectiveness of the NiD. Model approaches are inherently more consistent regarding calculation schemes, but without sound ground validation, have a risk of not accounting for regional differences in response of crop removal and water quality to nitrogen fertilization. For example, in the UK a model approach is used to estimate nitrogen loading as part of the NiD assessments. Loadings are calculated using the NEAP-N model (Lord and Anthony, 2000) along with an urban estimation model (Lerner, 2000). Leip et al. (2008) coupled the economic model CAPRI and the mechanistic biochemical model DNDC for evaluation of the effects of agrienvironmental policies on the European environment, for example on groundwater pollution with nitrate. Here we use the model MITERRA-EUROPE to apply a consistent methodology to all countries.

\subsection{MITERRA-EUROPE}

The model MITERRA-EUROPE (referred to as MITERRA hereafter) was used to quantify the nitrogen balances and nitrate leaching from agriculture on both EU-27 level, country level, and regional level. By applying a uniform calculation scheme as in MITERRA we could scrutinize results in the national reports and benchmark nitrogen surpluses and nitrate concentration at the more appropriate sub-national level. MITERRA consists of an input module with activity data and emission factors, a set of measures to mitigate ammonia and greenhouse gas emission and nitrate leaching, a calculation module, and an output module (Velthof et al., 2009; Lesschen et al., 2011). The database of MITERRA is on national and regional level (NUTS2, according Nomenclature of Territorial Units for Statistics in the EU) and includes data of $\mathrm{N}$ inputs, $\mathrm{N}$ outputs, livestock numbers, land use, crop types, soil type, and emission factors for $\mathrm{NH}_{3}, \mathrm{~N}_{2} \mathrm{O}$, and $\mathrm{NO}_{\mathrm{x}}$, and leaching factors for $\mathrm{NO}_{3}$.

For this paper we used an updated version of MITERRA as described in Velthof et al. (2011). Crop areas were derived from EUROSTAT at NUTS2 level and crop yields from FAOSTAT at national level as the EUROSTAT data was incomplete. Grassland yields and N contents of grassland were estimated using the methodology of Velthof et al. (2009), because grassland yields are not available from statistics. The number of livestock in each year was derived from EUROSTAT. Data on annual N fertilizer consumption were collected from FAOSTAT. The $\mathrm{N}$ excretion of all livestock categories except dairy cows were obtained from the GAINS model (Klimont and Brink, 2004). A method was developed to estimate the $\mathrm{N}$ excretion from dairy cows on regional level based on milk yields, grassland yields, and $\mathrm{N}$ inputs (Velthof et al., 2011).

The total manure $\mathrm{N}$ production was calculated at the NUTS2 level from the number of animals and the N excretion per animal and then corrected for gaseous $\mathrm{N}$ losses from buildings and storage. A method was developed to distribute the manure over crops taking account of the maximum 
Table 2. Precipitation surplus and fraction of nitrogen surplus leaching to groundwater, the fraction leaching to surface waters and the runoff fraction of $\mathrm{N}$ in applied fertilizer, grazing and manure, used in the MITERRA model.

\begin{tabular}{lcccc}
\hline & $\begin{array}{c}\text { Precipitation } \\
\text { surplus } \\
\text { mm }\end{array}$ & $\begin{array}{c}\text { Fraction leaching } \\
\text { to groundwater } \\
\%\end{array}$ & $\begin{array}{c}\text { Fraction leaching } \\
\text { to surface water } \\
\%\end{array}$ & $\begin{array}{c}\text { Fraction in } \\
\text { surface runoff } \\
\%\end{array}$ \\
\hline Belgium-Flemish & 396 & 23 & 9 & 3 \\
Belgium-Walloon & 479 & 11 & 12 & 4 \\
Denmark & 280 & 24 & 6 & 2 \\
Northern France & 356 & 13 & 10 & 5 \\
Germany & 295 & 13 & 10 & 4 \\
Ireland & 554 & 10 & 8 & 3 \\
Netherlands & 420 & 17 & 7 & 3 \\
United Kingdom & 450 & 11 & 10 & 3 \\
\hline
\end{tabular}

annual manure application of $170 \mathrm{~kg} \mathrm{Nha}^{-1}$ or higher in case of a derogation. Nitrogen fertilizer was distributed over crops relative to their nitrogen demand, taking account of the amount of applied manure and grazing manure and their respective fertilizer equivalence (Velthof et al., 2009). Further nitrogen inputs include biological $\mathrm{N}$ fixation, which is estimated as a function of land use and crop type (legumes) and nitrogen deposition that is derived at NUTS2 level from EMEP (EMEP, 2010).

Nitrogen leaching in MITERRA is calculated by multiplying the soil $\mathrm{N}$ surplus by a region specific leaching fraction, which is based on soil texture, land use, precipitation surplus, soil organic carbon content, temperature and rooting depth (Table 2). Surface runoff fractions are calculated based on slope, land use, precipitation surplus, soil texture and soil depth (Velthof et al., 2009). These parameters are derived from more detailed spatial data sources, and weighted average values for agricultural land are used at the NUTS2 level. The nitrate concentration in leaching water is calculated by dividing the amount of nitrogen leaching from agriculture by the total water flux, which is calculated as the precipitation surplus, derived from the EuroPearl model (Tiktak et al., 2006), minus surface runoff. The MITERRA model has been used in several EU studies and outcomes have been compared with other model results and national reported values. De Vries et al. (2011) compared several models, including MITERRA, on nitrogen budgets, and showed that MITERRA outcomes are in line with other model results. The distribution of calculated mean $\mathrm{NO}_{3}$ concentrations in NUTS 2 regions of EU-15 according to MITERRA agreed very well with the distribution of the means of measured $\mathrm{NO}_{3}$ concentrations in the EU-15, according to measured data from 2000-2003 (Velthof et al., 2009).

\section{Results}

\subsection{Characteristics of agriculture and nutrient use in northwestern EU}

Mean annual temperatures range between 8 and $12^{\circ} \mathrm{C}$, with minimum daily temperatures in January around $0{ }^{\circ} \mathrm{C}$ and maximum daily temperatures around $20^{\circ} \mathrm{C}$ in July. Mean annual precipitation ranges from values exceeding $1000 \mathrm{~mm}$ per year in western coastal regions to $500 \mathrm{~mm}$ per year in central France, and eastern UK and Germany (Tiktak et al., 2006). The combination of favorable climatic conditions, good agricultural practices and high inputs of fertilizer and manure allow high yields of cereals, potato, sugar beet, forage grass and maize and of milk, that generally exceed average values for the EU27 (Table 3). Yield differences per hectare in northwestern EU member states are largest for milk and ruminant meat because of large differences in shares of grazing beef and dairy cattle, areas of marginal grassland, grass in arable rotations (e.g. Denmark) and grazing intensity. Ireland, the UK and France hold large areas of less productive grassland on wet, peaty or mountain soils. All countries considered are net importers of substantial amounts of fodder and feed stuff, in the range of $200-400 \mathrm{~kg}$ per livestock unit (LSU; reference unit for livestock species based on feed requirement) in the period between 2000 and 2007 (FAOSTAT), with the exception of France $\left(120 \mathrm{~kg} \mathrm{LSU}^{-1}\right)$. These differences explain a minor part of differences in milk and ruminant meat yield per hectare.

Mean national livestock densities in the considered member states range between $0.9 \mathrm{LSU}$ per hectare in northern France, which is near to the average in the EU27, to 3.4 LSU per hectare in the Netherlands (Table 4; using LSU definition according to Eurostat). The share of dairy cows (one dairy cow represents one Livestock Unit; LSU) ranges from $10 \%$ in Denmark to $22 \%$ in Ireland. Regional livestock densities can be much higher, with $8.9 \mathrm{LSU} \mathrm{ha}^{-1}$ in the southeastern part of the Netherlands, 6.0 $\mathrm{LSU} \mathrm{ha}^{-1}$ in Flemish Region-Belgium and 3.7 $\mathrm{LSU} \mathrm{ha}^{-1}$ in Brittany-France, and 
Table 3. Mean annual yields in northwestern member states of the EU for cereals, forage maize, potato and sugar beet (Sources: FAOSTAT mean crop data are for the period 2000-2007; EFMA (2008), mean data for 2006-2009), and the sum of ruminant meat $+0.1 \times$ total milk production as a proxy for ruminant productivity per hectare of permanent grassland (Sources: production from FAOSTAT, data 2008, and grassland areas from Eurostat (2011), data 2007).

\begin{tabular}{|c|c|c|c|c|c|c|c|c|}
\hline & \multicolumn{4}{|c|}{ 2000-2007 } & $\begin{array}{l}\text { FAO } \\
2008\end{array}$ & EFMA & $\begin{array}{c}\text { EFMA } \\
2006-2009\end{array}$ & EFMA \\
\hline & $\begin{array}{l}\text { Wheat } \\
\text { ton ha }\end{array}$ & $\begin{array}{c}\text { Forage maize } \\
\text { ton } \mathrm{ha}^{-1}\end{array}$ & $\begin{array}{l}\text { Potato } \\
\text { ton ha }\end{array}$ & $\begin{array}{l}\text { Sugar beet } \\
\text { ton } \mathrm{ha}^{-1}\end{array}$ & $\begin{array}{l}\text { Meat }+0.1 \times \text { Milk } \\
\text { ton ha }{ }^{-1} \text { grass land }\end{array}$ & $\begin{array}{l}\text { All cereals } \\
\text { ton } \mathrm{ha}^{-1}\end{array}$ & $\begin{array}{l}\text { Potato } \\
\text { ton ha }\end{array}$ & $\begin{array}{l}\text { Sugar beet } \\
\text { ton ha }\end{array}$ \\
\hline Belgium & 8.2 & 11.1 & 43.4 & 67.9 & 1.09 & 8.8 & 46.0 & 65.0 \\
\hline Denmark & 7.1 & & 39.5 & 57.3 & 1.67 & 5.9 & 44.7 & 55.7 \\
\hline France & 6.9 & 8.6 & 41.4 & 76.5 & 0.50 & 7.2 & 45.7 & 82.5 \\
\hline Germany & 7.3 & 8.8 & 40.9 & 59.1 & 0.85 & 6.5 & 40.1 & 58.0 \\
\hline Ireland & 8.9 & & 35.2 & 48.6 & 0.36 & 7.0 & 32.8 & \\
\hline Netherlands & 8.2 & 11.2 & 43.5 & 61.6 & 1.85 & 8.2 & 46.3 & 63.2 \\
\hline United Kingdom & 7.7 & & 41.6 & 54.7 & 0.25 & 7.1 & 41.6 & 61.7 \\
\hline EU27 & & & & & 0.43 & 5.0 & 29.0 & 62.1 \\
\hline
\end{tabular}

Table 4. Main characteristics of agricultural sector in northwestern member states of the EU in 2007 (Eurostat, 2011).

\begin{tabular}{lrrrr}
\hline & $\begin{array}{r}\text { Agricultural } \\
\text { area (UAA) } \\
\text { mln ha }\end{array}$ & $\begin{array}{r}\text { Livestock } \\
\text { density } \\
\text { LSU ha }^{-1^{\mathrm{a}}}\end{array}$ & $\begin{array}{r}\text { Permanent } \\
\text { Pasture } \\
\text { of UAA }\end{array}$ & $\begin{array}{r}\text { Farm size } \\
\text { ha UAA/holding }\end{array}$ \\
\hline Belgium & 1.4 & 2.8 & 37 & 29 \\
Denmark & 2.7 & 1.7 & 8 & 60 \\
France & 27.5 & 0.8 & 29 & 53 \\
North-central & 17.8 & 0.9 & 21 & - \\
Germany $_{\text {Ireland }}$ & 16.9 & 1.1 & 29 & 46 \\
Netherlands & 4.1 & 1.4 & 76 & 32 \\
United Kingdom & 1.9 & 3.4 & 43 & 65 \\
EU27 & 16.1 & 0.9 & 62 & 13 \\
\hline
\end{tabular}

${ }^{a}$ In the EUROSTAT definition one LSU corresponds to the feed requirement of one adult dairy cow producing $3000 \mathrm{~kg}$ of milk annually.

b All departments above the line "Nantes-Dijon".

are always associated with the presence of a large pig and/or poultry sector. Farm sizes per holding in the northwestern member states are much higher than the EU27 average.

Nitrogen from manures constitutes a substantial proportion of total nitrogen fertilization, ranging between $40 \%$ in Germany and Northern France, to $60-65 \%$ in Belgium, Ireland and the Netherlands. In the Netherlands and the Flemish Region the net nitrogen excretion (after subtracting ammonia emission from housing and storage) exceeds the application limit of $170 \mathrm{~kg} \mathrm{ha}^{-1}$ set by the $\mathrm{NiD}$, by 40 and $12 \mathrm{~kg} \mathrm{ha}^{-11}$ respectively, based on MITERRA results. These two countries require a combination of derogation, on the one hand, and export and processing of manure on the other hand, to be able to comply with the NiD at a national level. The sum of nitrogen excretion plus fertilizer use per hectare of utilized

\footnotetext{
${ }^{1}$ Unless indicated otherwise the unit $\mathrm{kg} \mathrm{ha}^{-1}$ refers to annual fluxes.
}

agricultural area (UAA) in the period 2005-2008 ranges between $138 \mathrm{~kg} \mathrm{ha}^{-1}$ in France to $377 \mathrm{~kg} \mathrm{ha}^{-1}$ in the Netherlands (Table 5) and exceeds mean values for EU12 (old member states) and EU27.

\subsection{Application standards for nitrogen from manure and fertilizer}

The most important restriction following from the NiD is the application limit for nitrogen from animal manure. Other restrictions following from the NiD are mandatory minimum manure storage capacities, prohibition periods for nutrient application, restrictions for nutrient application near water courses, on slopes and on frozen, waterlogged or snowcovered soils (van Dijk and ten Berge, 2009; Table 6). These restrictions should facilitate the achievement of the overall objective of the NiD to establish a balance between nutrient application and crop requirements. There are large 
Table 5. Average annual inputs, crop removal and gross balance of nitrogen in 2005-2008 in northwestern member states of the EU (Eurostat, 2012).

\begin{tabular}{lrrrrr}
\hline \multirow{2}{*}{ Fertilizer } & $\begin{array}{r}\text { Inorganic } \\
\text { manure }\end{array}$ & Gross & Other inputs & Removal & $\begin{array}{r}\text { Gross N } \\
\text { balance }\end{array}$ \\
\hline & \multicolumn{5}{c}{$\mathrm{kg} \mathrm{Nha}^{-1}$} \\
Belgium & 101 & 168 & 41 & 191 & 119 \\
Denmark & 75 & 100 & 24 & 101 & 98 \\
France & 76 & 62 & 26 & 112 & 52 \\
Germany & 103 & 74 & 42 & 125 & 93 \\
Ireland & 78 & 117 & 15 & 155 & 55 \\
Netherlands & 140 & 236 & 28 & 194 & 210 \\
United Kingdom & 94 & 87 & 31 & 111 & 101 \\
EU15* & 67 & 63 & 26 & 98 & 58 \\
EU27 & 61 & 54 & 25 & 89 & 50 \\
\hline
\end{tabular}

* EU15: member states between 1 January 1995 and 30 April 2004.

Table 6. Restrictions for application of fertilizer and manure in national implementations of the Nitrates Directive (Adapted from Dijk and Berge, 2009).

\section{$\begin{array}{lllllll}\text { DK } & \text { BFL } & \text { FR } & \text { GE}^{1} & \text { UK } & \text { NL } & \text { IRL }\end{array}$}

\begin{tabular}{|c|c|c|c|c|c|c|c|}
\hline \multicolumn{8}{|l|}{ Farm measures } \\
\hline \multicolumn{8}{|l|}{ Fertilizer planning } \\
\hline Keeping records & yes & yes & yes & yes & yes & yes & yes \\
\hline Soil analysis & yes & yes $^{2}$ & & yes & & yes $^{2}$ & \\
\hline \multicolumn{8}{|l|}{ Fertilization } \\
\hline Closed periods for manure/fertilizers ${ }^{3}$ & yes & yes & yes $^{4}$ & yes & yes & yes & yes \\
\hline Low emission application & yes & yes & & & & yes & \\
\hline No manure application on frozen, snow covered and waterlogged land & yes & yes & yes $^{4}$ & yes & yes & yes & yes \\
\hline Unfertilised zones along surface water ${ }^{5}$ & yes $^{6}$ & yes & yes $^{4}$ & yes & yes & yes & yes $^{7}$ \\
\hline \multicolumn{8}{|l|}{ Post-harvest measures } \\
\hline Catch crops & yes & & yes $^{4}$ & & & yes & \\
\hline No tillage in autumn & yes & & & & & & yes $^{8}$ \\
\hline \multicolumn{8}{|l|}{ Other Policy Measures } \\
\hline Max limit for livestock & yes & & & & & & \\
\hline \multicolumn{8}{|l|}{ Maximum limits on $N$ and $P$ use } \\
\hline Manure & yes & yes & yes & yes & yes & yes & yes \\
\hline Total N (manure + fertilizers) & yes & yes & yes $^{4}$ & & yes & yes & yes \\
\hline Maximum $\mathrm{N}$ and $\mathrm{P}$ surpluses & & & & yes & & & \\
\hline Maximum soil mineral $\mathrm{N}$ in autumn & & yes & yes $^{9}$ & yes $^{1}$ & & & \\
\hline
\end{tabular}

$\mathrm{DK}=$ Denmark, BFL = Belgium Flemish Region, FR = France, GE = Germany, UK $=$ United Kingdom, NL $=$ The Netherlands, IRL $=$ Ireland

${ }^{1}$ Implementation varies between states (Länder) of Germany, e.g. maximum soil mineral N autumn only in Baden Wurtemberg.

${ }^{2}$ For NL in case farm has derogation. For BFL from 2013, on fields exceeding the threshold value of maximum soil mineral N in autumn.

3 For liquid manures generally between September/October and February.

${ }^{4}$ In some departments within the NVZ's. E.g. catch crops in western regions (Brittany and Normandy); Anonymous (2008a).

5 With large variation in width and length of unfertilized zones.

6 Increased from $2 \mathrm{~m}$ to $10 \mathrm{~m}$ from 2012 onwards.

${ }^{7}$ No fertilizer within 2 meters of surface water.

8 Ploughing between July and November if green cover emergence of planted crop within 6 weeks of ploughing.

${ }^{9}$ In small highly sensitive areas (e.g. coastal areas with green tides). 
Table 7. Overview of area in Nitrate Vulnerable Zones and derogations for grassland (mostly dairy) farms in 2009 (European Commission, 2011).

\begin{tabular}{lllrr}
\hline & $\begin{array}{l}\text { Nitrate } \\
\text { Vulnerable } \\
\text { Zones area }(\%)\end{array}$ & $\begin{array}{l}\text { Application } \\
\text { limit for manure } \\
\left(\mathrm{kg} \mathrm{N} \mathrm{ha}^{-1}\right)\end{array}$ & $\begin{array}{r}\text { Share of } \\
\text { Agricultural } \\
\text { land }(\%)\end{array}$ & $\begin{array}{r}\text { Share of } \\
\text { farms } \\
(\%)\end{array}$ \\
\hline Belgium & 68 & & & \\
$\quad$ Flemish Region & 100 & $250 / 200^{1}$ & 12 & 10 \\
$\quad$ Walloon Region & $42^{2}$ & & & \\
Denmark & 100 & 230 & 4 & 3.2 \\
France & 45 & 170 & 0 & 0 \\
Germany & 100 & 230 & $<1$ & $<1$ \\
Ireland & 100 & 250 & 45 & 8 \\
Netherlands & 100 & 250 & 1.5 & 1.3 \\
United Kingdom & 39 & 250 & & \\
\hline Also a derogation for some arable crops. ${ }^{2}$ Situation in 2007 (Anonymous, 2008b).
\end{tabular}

discrepancies between countries regarding the way these restrictions are translated into national law and applied in practice. Large discrepancies exist for methods of estimation of $\mathrm{N}$ emissions by livestock (including volatilization coefficients for ammonia), definitions of periods when and areas where manure application is restricted, procedures for enforcement of regulations can be very different and hamper a strict comparison of environmental impacts of the NiD between countries.

With the exception of France, all member states have negotiated with the EU Commission an extension of the application limit in the $\mathrm{NiD}$ of $170 \mathrm{~kg} \mathrm{~N} \mathrm{ha}^{-1}$ for manure from ruminants (a so-called derogation; Table 7). These derogations are based on proof that this extension will not increase the risk for exceeding the critical nitrate limit of $50 \mathrm{mg} \mathrm{NO}_{3}^{-} \mathrm{L}^{-1}$ in groundwater and surface water. Derogations are granted at farm level (except in the Flemish Region) and mostly apply to farms with at least 70-80\% of farm land in use for grassland (or roughage in Denmark). The Flemish Region has a derogation at field level and includes some arable crops. For grassland and forage maize followed by one cut of grass or cut rye the application limit is $250 \mathrm{~kg} \mathrm{~N} \mathrm{ha}^{-1}$ as cattle manure or treated pig manure and $200 \mathrm{~kg} \mathrm{Nha}^{-1}$ for beet and winter wheat followed by a catch crop (Table 7). Denmark has implemented a maximum application limit for arable land of $140 \mathrm{~kg} \mathrm{ha}^{-1}$ of nitrogen from pig manure and on organic farms (Kronvang et al., 2008), which is beyond the requirements of the NiD. The Netherlands has the largest derogation both regarding the extension of the application limit itself, and regarding the area where this extension applies.

Only the NiD action programs of the Netherlands, Denmark and the Flemish Region have introduced crop and soil type-dependent applications standards for total $\mathrm{N}$ inputs, from manures and mineral fertilizers (van Dijk and ten Berge, 2009). Application standards in the Netherlands and Denmark apply to fertilizer equivalent (FE) N (Table 8). In Denmark, Ireland, the Netherlands and the UK for some crops, standards are differentiated with actual yield level and target. For cereals different standards may apply to baking, malting and fodder qualities, for potato to cultivars for use as ware, french fry, starch and seed. In the Flemish Region farmers can choose between a fixed total nitrogen amount or FE N values for organic fertilizers per crop. This new system with some new limits has been introduced in 2011 (Anonymous, 2011). In Denmark, Ireland and the UK application standards also depend on the soil $\mathrm{N}$ status and cropping history.

Differences between total FE N application standards for the Flemish Region, the Netherlands and Denmark can be quite considerable. While standards for forage maize and winter wheat on sandy soils are quite comparable, differences between standards for other crops and clay soils are higher, amounting to $110 \mathrm{~kg} \mathrm{~N} \mathrm{ha}^{-1}$ for ware potato on clay between the Netherlands and Denmark (Table 8). As a whole, the standards are the highest in the Netherlands for most crops mentioned in Table 8. For grassland without clover, standards are highest in Denmark, however, grass with clover is predominant in Denmark, and has lower standards. Standards for winter wheat and, to a lesser extent, for forage maize in Denmark and the Flemish Region are comparable. On the other hand, the standards for potato and sugar beet are lower for Denmark compared to the Flemish Region while this is the reverse for grassland. One would expect application standards in Denmark to be lower than in the Flemish Region in view of a lower yield potential (Table 3) and taking into account that in Denmark the fertilization limits are set at $90 \%$ of the economic optimum N-fertilization.

The consequence for Denmark, the Flemish Region, and the Netherlands of having a legal system of application standards based on total FE nitrogen is the introduction of fixed statutory values for the fertilizer equivalency of manures. Also the UK and Ireland have statutory values for the FE of manure in their NiD action programs. When statutory FE values are lower than actual values they provide an incentive 
Table 8. Nitrogen application standards $\left(\mathrm{kg} \mathrm{N} \mathrm{ha}^{-1} \mathrm{yr}^{-1}\right)$ for some major crops in the 4th action programs for the NiD expressed either as fertilizer equivalent $\mathrm{N}(\mathrm{FE})$ or total $\mathrm{N}$.

\begin{tabular}{|c|c|c|c|c|c|c|c|}
\hline & & Soil & $\begin{array}{l}\text { Grass: } \\
\text { graze } \\
\text { and cut }\end{array}$ & $\begin{array}{l}\text { Forage } \\
\text { maize }\end{array}$ & $\begin{array}{l}\text { Winter } \\
\text { wheat }\end{array}$ & $\begin{array}{l}\text { Potato } \\
\text { (ware) }\end{array}$ & $\begin{array}{l}\text { Sugar } \\
\text { beet }\end{array}$ \\
\hline \multirow{2}{*}{ Netherlands } & $\mathrm{FE}$ & sand & 260 & 150 & 160 & 245 & 145 \\
\hline & $\mathrm{FE}$ & clay & 310 & 185 & 220 & 250 & 150 \\
\hline \multirow{2}{*}{ Denmark $^{1,2}$} & $\mathrm{FE}$ & sand & $310^{5}$ & 150 & ${ }^{3} 150$ & 140 & 110 \\
\hline & $\mathrm{FE}$ & clay & $330^{5}$ & 155 & ${ }^{4} 180$ & 140 & 120 \\
\hline \multirow{4}{*}{ Flemish Region } & $\mathrm{FE}^{8}$ & sand & 235 & 135 & 160 & 190 & 135 \\
\hline & $\mathrm{FE}^{8}$ & clay & 245 & 150 & 175 & 210 & 150 \\
\hline & total & sand & 350 & 205 & 200 & 260 & 205 \\
\hline & total & clay & 360 & 220 & 215 & 280 & 220 \\
\hline United Kingdom & total & all & 330 & 150 & 220 & 270 & 120 \\
\hline Ireland 6 & total & all & ${ }^{7} 306$ & 140 & 180 & 145 & 155 \\
\hline
\end{tabular}

to farmers to increase the nitrogen efficiency of the organic manure. Low fertilizer equivalencies for manure are typically caused by gaseous losses of ammonia, $\mathrm{N}$ oxides and dinitrogen, leaching losses of nitrate outside the growing season and slow $\mathrm{N}$ release within the growing season. FE's can be increased by using low emission manure application techniques and by improved management of manure and soil (Dalgaard et al., 2011), for example by replacing autumn application of manure by spring application. Increasing legal FE may provide a strong incentive to apply these techniques and to improve management of manure.

Generally speaking, a legal system based on FE is more comparable to the system for $\mathrm{N}$ recommendation than a system based on total $\mathrm{N}$ and therefore provides the farmer more direct insight into whether he needs to improve his $\mathrm{N}$ management to ensure sufficient $\mathrm{N}$ supply to crops. The statutory FE values do not always correspond to FE used in fertilizer recommendations (ten Berge and Dijk, 2009). For slurry, statutory FEs range from about $20 \%$ in the UK to $75 \%$ in Denmark. The small values quoted for the UK imply that the manures are not applied using techniques to reduce ammonia emission. For solid poultry, manure FEs range from $30 \%$ in the UK, the Flemish Region and Germany to 55-65\% in Denmark and the Netherlands (Webb et al., 2013; Table 9). In Ireland maximum FE for manure of $40 \%$ have been reported (Hoekstra et al., 2011).

In Germany there are no legal $\mathrm{N}$ application limits for total or FE nitrogen. Instead, there is a restriction on net $\mathrm{N}$ surplus at farm level in combination with statutory FE values. The farmers have the responsibility to plan fertilization in such a way that the three year average of the $\mathrm{N}$ surplus does not exceed $60 \mathrm{~kg} \mathrm{~N} \mathrm{ha}^{-1}$ from 2009 onwards. This surplus con- straint has been introduced stepwise since 2006 (Wolter et al., 2011).

France does not prescribe application standards in its action program for zones vulnerable to nitrate leaching (NVZ's). For France FE values vary with crops (spring versus winter) and application period but have no legal status (COMIFER, 2011). Total $\mathrm{N}$ inputs are limited only in areas where nitrate concentrations in ground or surface water are high and where that water is used for drinking water. This limit is $210 \mathrm{~kg} \mathrm{Nha}^{-1}$ in parts of Brittany, while in some watersheds with nitrate in surface water exceeding $50 \mathrm{mg} \mathrm{L}^{-1}$ total $\mathrm{N}$ inputs are restricted to values as low as $140 \mathrm{~kg} \mathrm{~N} \mathrm{ha}^{-1}$ (van Dijk and ten Berge, 2009). Restrictions for use of fertilizers (and other agrochemicals like pesticides) in drinking water abstraction areas are common in Europe, also before the introduction of the $\mathrm{NiD}$.

\subsection{Nitrogen balance}

Complete official reports to the EU of the effect of the national action plans for the NiD are available for the 3rd (2000-2003) and 4th (2004-2007) reporting period and summarized by the European Commission (2011). A high gross nitrogen balance (GNB) is always associated with high gross inputs of manure (Table 5). In all countries considered, the GNB decreased between 2000 and 2008 (Fig. 1). The decrease of GNB between 2000 and 2004 is larger than between 2004 and 2008. The decrease in the Netherlands was $80 \mathrm{~kg} \mathrm{ha}^{-1}$ and largest, but the GNB in 2008 is still higher than for other countries. The relative decreases of the GNB between 2000 and 2008 in Belgium (31\%), Ireland $(25 \%)$ and the United Kingdom (23\%) are comparable to 
Table 9. Statutory nitrogen fertilizer equivalency (\%) for application of most common manure types (after deduction of gaseous losses from buildings and storage; taken from Webb et al., 2013).

\begin{tabular}{lrrrr}
\hline & $\begin{array}{r}\text { Cattle } \\
\text { slurry }\end{array}$ & $\begin{array}{r}\text { Pig } \\
\text { slurry }\end{array}$ & $\begin{array}{r}\text { Layer solid } \\
\text { manure }\end{array}$ & $\begin{array}{r}\text { Broiler solid } \\
\text { manure }\end{array}$ \\
\hline Netherlands & 60 & $60-70$ & 55 & 55 \\
Flemish Region & 60 & 60 & 30 & 30 \\
Denmark $_{\text {France* }}^{*}$ & 70 & 75 & 65 & 65 \\
Germany & $50-60$ & $50-75$ & $45-65$ & $45-65$ \\
United Kingdom & 50 & 60 & 30 & 30 \\
Ireland & $20 / 35$ & $25 / 50$ & $20 / 35$ & $20 / 30$ \\
& 40 & 50 & 50 & 50 \\
\hline
\end{tabular}

* No legal status.

the decrease in the Netherlands $(30 \%)$. The major cause for a decrease of the GNB is the decrease of the use of chemical fertilizer. In Denmark and the Netherlands this decrease was instigated to a large extent by increased utilization of manure N (Mikkelsen et al., 2010; Dalgaard et al., 2012).

Nitrogen balance calculations using MITERRA provide insight in soil inputs and outputs underlying the differences in the $\mathrm{N}$ balance (Table 10). MITERRA results for $\mathrm{N}$ removal $\left(R^{2} 0.92\right), \mathrm{GNB}\left(R^{2} 0.94\right)$ and even more so $\mathrm{SNB}\left(R^{2} 0.96\right)$ are significantly correlated with total $\mathrm{N}$ input from manure and fertilizer but results for individual countries may deviate from the average relation. This is the case for Ireland in view of dominant grazing sector. In the Netherlands and the Flemish Region the difference between total $\mathrm{N}$ excretion and actual manure application is larger than for other countries because of substantial net export and processing of manure from pigs and poultry, amounting to $18 \mathrm{~kg} \mathrm{Nha}^{-1}$ and $54 \mathrm{~kg} \mathrm{Nha}^{-1}$ in 2008, respectively. Flemish pig manure is mostly processed by waste water treatment where $\mathrm{N}$ is removed by denitrification. In the Netherlands the five provinces with an intensive pig and poultry sector export on average $127 \mathrm{~kg} \mathrm{Nha}^{-1}$ to the other seven provinces and a small part (10-20 $\mathrm{kg} \mathrm{N} \mathrm{ha}^{-1}$ ) abroad, mainly to Germany.

Comparing nitrogen surpluses at national level for the northwestern EU member states is not very informative because of large differences in agricultural structure and livestock intensity within these countries (Table 4). Therefore, nitrogen use and balance by MITERRA model at NUTS2 level were recombined to generate results for regions with similar UAA (Fig. 2). Eleven regions had an SNB exceeding $100 \mathrm{~kg} \mathrm{~N} \mathrm{ha}^{-1}$. In addition to the Netherlands and Belgium, Brittany in France is standing out while several regions in the UK and single regions in Germany, Ireland and France have an SNB modestly exceeding $100 \mathrm{~kg} \mathrm{~N} \mathrm{ha}^{-1}$. Zooming further into MITERRA results for the Netherlands and Belgium, we find greatest surpluses for 2008 in the Province of Antwerp $\left(241 \mathrm{~kg} \mathrm{~N} \mathrm{ha}^{-1}\right)$, and the southeast of the Netherlands (mean value $191 \mathrm{~kg} \mathrm{Nha}^{-1}$ and maximum value of $197 \mathrm{~kg} \mathrm{Nha}^{-1}$ in the province of Noord Brabant). These regions with the

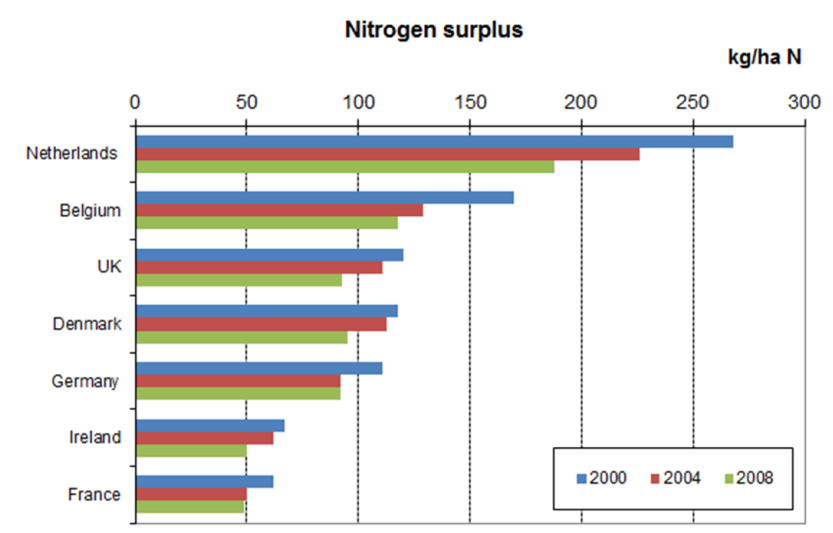

Fig. 1. Gross annual nitrogen balance between 2000 and 2008 (Eurostat, 2011).

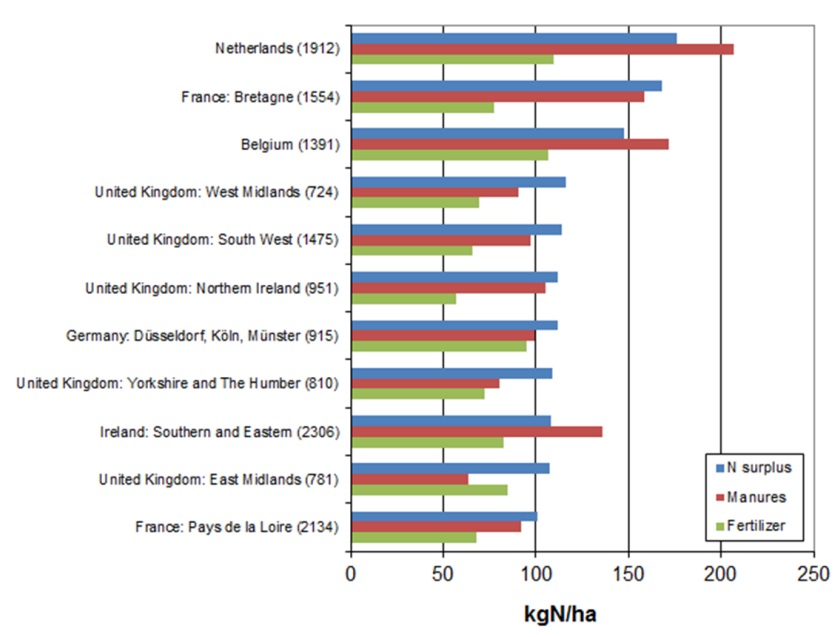

Fig. 2. Annual soil $\mathrm{N}$ balance (soil $\mathrm{N}$ surplus) and $\mathrm{N}$ inputs from manure and fertilizer in 2008 by MITERRA for regions in northwestern Europe of comparable UAA and $\mathrm{N}$ surplus exceeding $100 \mathrm{~kg} \mathrm{~N} \mathrm{ha}^{-1}$ (NUTS1 level or clusters of NUTS2; UAA in 1000 ha in between brackets).

greatest $\mathrm{N}$ surplus are also most sensitive to nitrate leaching with MITERRA leaching fractions of $18 \%$ in Brittany, $22 \%$ in the Flemish Region (26\% in Province of Antwerp), $24 \%$ in southeast of the Netherlands (33\% in the province of Noord Brabant).

GNB by MITERRA for the seven considered countries in 2008 is on average $19 \mathrm{~kg} \mathrm{ha}^{-1}$ higher than GNB in Eurostat and fairly well correlated $\left(R^{2} 0.74\right)$. Major outliers are Belgium and Ireland with differences of 38 and $58 \mathrm{~kg} \mathrm{ha}^{-1}$, respectively, the possible causes of which will be addressed in the discussion.

\subsection{Water quality}

In view of different monitoring procedures and differences in hydrology, geology and soils in the considered member 
Table 10. Annual N inputs, removal of soil $\mathrm{N}$ balance in 2008 in northwestern member states of the EU according to MITERRA ranked with SNB.

\begin{tabular}{lrrrrrrrr}
\hline & $\begin{array}{r}\text { UAA } \\
\text { mln ha }\end{array}$ & $\begin{array}{r}\text { Total N } \\
\text { excretion }\end{array}$ & $\begin{array}{r}\text { Applied } \\
\text { manure }\end{array}$ & Grazing & $\begin{array}{r}\text { Applied } \\
\text { fertilizer } \\
\mathrm{kg} \mathrm{Nha}^{-1}\end{array}$ & $\begin{array}{r}\text { Total N } \\
\text { soil input }\end{array}$ & $\begin{array}{r}\text { N } \\
\text { removal }\end{array}$ & SNB \\
\hline Netherlands & 1.9 & 264 & 140 & 67 & 110 & 356 & 179 & 176 \\
Belgium & 1.3 & 187 & 76 & 54 & 107 & 272 & 149 & 124 \\
Flemish R. Region & 0.7 & 281 & 109 & 63 & 107 & 314 & 166 & 147 \\
Walloon R. & 0.7 & 114 & 51 & 47 & 107 & 240 & 135 & 105 \\
Ireland & 4.1 & 138 & 46 & 81 & 81 & 228 & 132 & 94 \\
North. France & 17.8 & 65 & 29 & 24 & 75 & 154 & 87 & 66 \\
United Kingdom & 14.3 & 70 & 23 & 35 & 64 & 143 & 72 & 66 \\
Denmark & 2.5 & 95 & 67 & 11 & 69 & 170 & 106 & 65 \\
Germany & 16.7 & 79 & 49 & 13 & 93 & 186 & 122 & 64 \\
France & 30.1 & 57 & 24 & 23 & 67 & 137 & 80 & 56 \\
EU27 & 172.5 & 57 & 27 & 19 & 61 & 127 & 67 & 59 \\
\hline
\end{tabular}

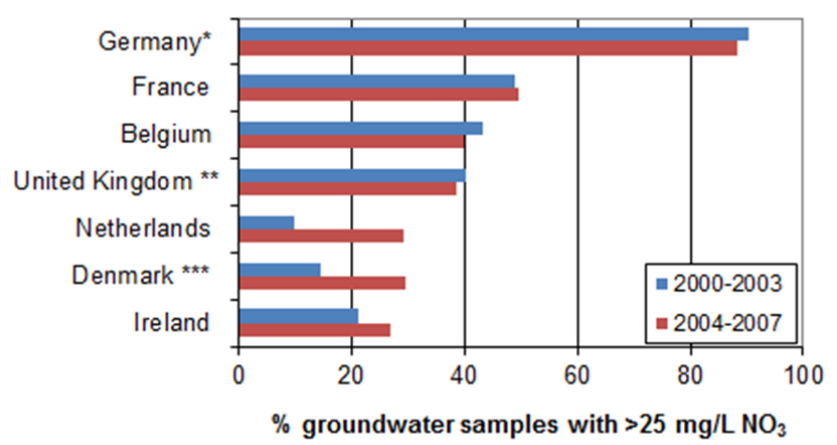

Fig. 3. Percentage of groundwater samples in monitoring programs for the Nitrates Directive exceeding $25 \mathrm{mg} \mathrm{NO}_{3} \mathrm{~L}^{-1}$ for the $2 \mathrm{nd}$ and 3rd reporting period (European Commission, 2011). * For Germany only data for the agriculture monitoring network ** For the reporting period 2000-2003 United Kingdom reported only stations within England. *** For the reporting period 2000-2003 Denmark provided aggregated results.

states, reports to the EU Commission of nitrate concentrations in groundwater exceeding a policy target (in this case the nitrate limit for drinking water) do not provide direct insight in the effectiveness of NiD action programs or in the impact of differences of nitrogen balances. This is perhaps most strikingly illustrated in the Netherlands where mean nitrate concentrations in groundwater are low (Fig. 3) while the GNB is highest (Figs. 1 and 2). In part differences in the nitrate response between reporting periods and between countries are artifacts of different monitoring procedures and data selections. For example the apparent increase of nitrate concentrations in Denmark and the Netherlands between 2000-2003 and 2004-2007 in the EU dataset (European Commission, 2011) is an artifact of inclusion of observations in the uppermost groundwater in the 2004-2007 EU dataset. But differences in the nitrate response between coun- tries mainly have hydrogeochemical causes like the presence of relatively deep soils, high groundwater tables and high organic matter contents (in part as peaty soils) promoting denitrification. Some areas in the UK have deep unsaturated extents through which the travel time for nitrate may be several decades (Wang et al., 2012). Analysis of lag times required for improvements of groundwater nitrate levels in Ireland showed that the achievement of good water quality status for some water bodies may be too optimistic but improvements are predicted within subsequent 6- and 12-yr cycles (Fenton et al., 2011). Analyzing a $50 \mathrm{yr}$ time series of SNB and nitrate concentration in groundwater in Denmark, Hansen et al. (2011) found that nitrate concentrations have been decreasing since 1980 . They found that the frequency of downward nitrate trends in groundwater samples clearly increased with lower recharge age, providing proof that younger groundwater responds fastest to decreasing trends of SNB. Hansen et al. (2012) further found that nitrate concentration decreased significantly more in areas with a high livestock density. Reported nitrate concentrations in Germany are higher than in the other northwestern EU member states because sampling is restricted to agricultural soils and focused on polluted regions. Changes in monitoring procedures and densities do not allow solid conclusions on nitrate trends between the $3 \mathrm{rd}$ and 2 nd reporting period based on the total dataset of groundwater observations. However, the overall picture appears to be that nitrate concentrations did not change between 2000 and 2007. In shallow groundwater, which responds most directly to NiD action programs, $60 \%$ of all samples in the EU27 were below $25 \mathrm{mg} \mathrm{NO}_{3} \mathrm{~L}^{-1}$, and $20 \%$ above the NiD target of $50 \mathrm{mg} \mathrm{NO}_{3} \mathrm{~L}^{-1}$ (European Commission, 2011). More insight into trends may be obtained by selecting data for shallow phreatic groundwater directly from official national NiD reports for the Netherlands (Zwart et al., 2008), the Flemish Region (Desimpelaere et al., 2008), Walloon region, Ireland, Germany and Denmark 


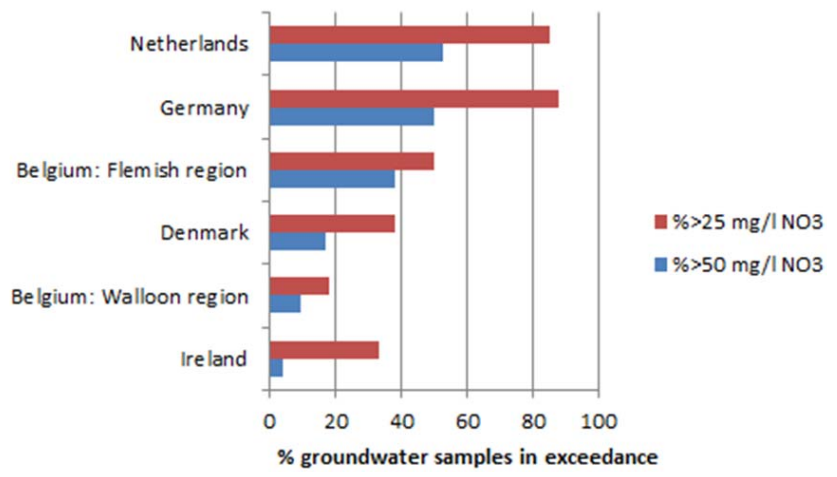

Fig. 4. Percentage of shallow phreatic groundwater samples in monitoring programs for the Nitrates Directive for the 3 rd reporting period (2004-2007) exceeding 25 or $50 \mathrm{mg} \mathrm{NO}_{3} \mathrm{~L}^{-1}$.

(Anonymous, 2008b, c, d, e), (Fig. 4). Here differences of nitrate concentration between countries appear to be more in accordance with differences of the nitrogen balance (Fig. 1).

In countries with a long running monitoring network for nitrate in the upper, sometimes shallow, groundwater in sandy phreatic aquifers (Fig. 5) a slow to moderate decrease of nitrate concentration can be observed. The mean decrease of the nitrate concentration in the monitoring period is largest in the Netherlands $\left(6 \mathrm{mg} \mathrm{NO}_{3} \mathrm{~L}^{-1}\right.$ per year), followed by Denmark $\left(2 \mathrm{mg} \mathrm{NO}_{3} \mathrm{~L}^{-1}\right.$ per year), Germany $\left(0.6 \mathrm{mg} \mathrm{NO}_{3} \mathrm{~L}^{-1}\right.$ per year), Flemish Region $\left(0.7 \mathrm{mg} \mathrm{NO}_{3} \mathrm{~L}^{-1}\right.$ per year) and finally the Walloon region with a small increase $\left(0.3 \mathrm{mg} \mathrm{NO}_{3} \mathrm{~L}^{-1}\right.$ per year). These trends do not only reflect the effect of the measures from implementation of the NiD, but also on changes in agricultural practices and effects of implementation of other policies, e.g., measures for reducing ammonia emission. Trends further depend on sampling depth and travel time of infiltrating water which differ spatially within countries and between countries.

Observed nitrate exceedance in the period 2004-2007 (Fig. 4) and nitrate concentrations between 2005 and 2010 (Fig. 5), both in upper levels of phreatic groundwater, agree fairly well with modeled nitrate concentrations in leaching water in 2008 using MITERRA (Figs. 6 and 7). Some level of disagreement is to be expected considering that nitrate concentrations in leaching water will tend to be higher than in groundwater, and that monitoring data are not always representative for nitrate concentration in total UAA. In Germany, observed concentrations are higher than MITERRA results in view of the intended focus of the monitoring program on areas with high nitrate concentrations (Anonymous, 2008d).

MITERRA results for NUTS2 regions with mean area weighted nitrate concentrations exceeding $50 \mathrm{mg} \mathrm{NO}_{3} \mathrm{~L}^{-1}$ are found only in the Netherlands, the Flemish Region, the western part of Germany and in Brittany (Fig. 7). SNB values exceeding $100 \mathrm{~kg} \mathrm{Nha}^{-1}$ in regions in the UK and Ireland (Fig. 2) do not lead to exceedance of the nitrate target

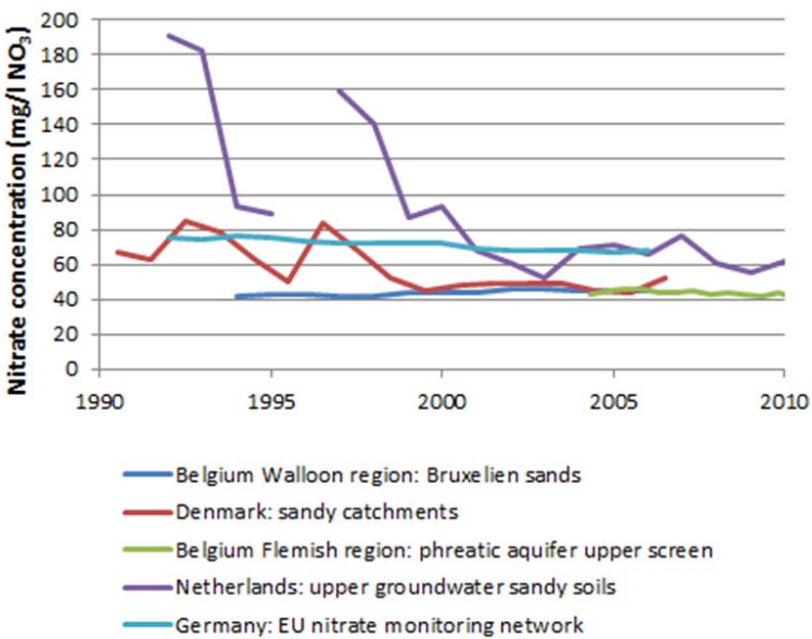

Fig. 5. Trend of nitrate concentrations in upper levels of phreatic groundwater in sandy soils, catchments or aquifers in monitoring programs for the Nitrates Directive (Data taken from Fraters et al., 2011).

of the NiD as a result of relatively low nitrate leaching fractions in these regions. However, the risk of exceedance of ecological limits for nitrate or nitrogen in surface water will be higher in regions with high SNB.

The EU Water Framework Directive gives room to member states to define and differentiate national standards for good ecological status or potential. A nitrate limit concentration of $10 \mathrm{mg} \mathrm{NO}_{3} \mathrm{~L}^{-1}\left(2 \mathrm{mg} \mathrm{N} \mathrm{L}^{-1}\right)$ was used as a proxy for the nitrate limit in fresh waters (Cardoso et al., 2001). Surface waters with mean nitrate concentration greater than $10 \mathrm{mg} \mathrm{NO}_{3} \mathrm{~L}^{-1}$ ranged from $20 \%$ in Ireland to $60 \%$ in Germany (Fig. 8). Between 2000 and 2007 the percentage of surface water samples exceeding $10 \mathrm{mg} \mathrm{NO}_{3} \mathrm{~L}^{-1}$ shows a small decrease, when looking to the total population of fresh surface water samples reported to the EU Commission (Fig. 8). Differences between countries do not seem to have a clear relation with observed exceedance in groundwater. Again, in part these differences reflect different response mechanisms and response times and nitrate attenuation during transport from groundwater to surface water (Fenton et al., 2009). However, differences in response time will be less than for deeper groundwater bodies. In particular, response of surface water nitrate to restrictions on how and when to apply manure and fertilizer (Table 6) should be faster, due to the shorter transport pathways compared to deeper aquifers, while full response to restrictions on application levels may take decades. 


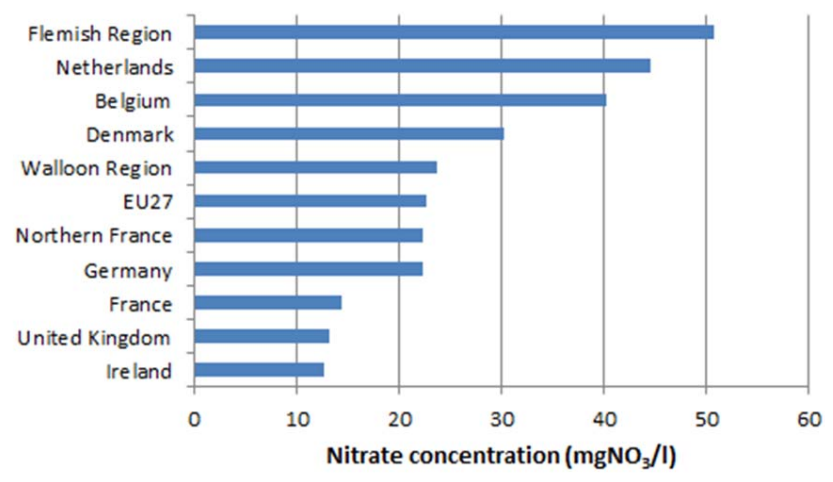

Fig. 6. Mean nitrate concentration (UAA and precipitation surplus weighted) in leaching water from agricultural soils in northwestern EU in 2008 by MITERRA model.

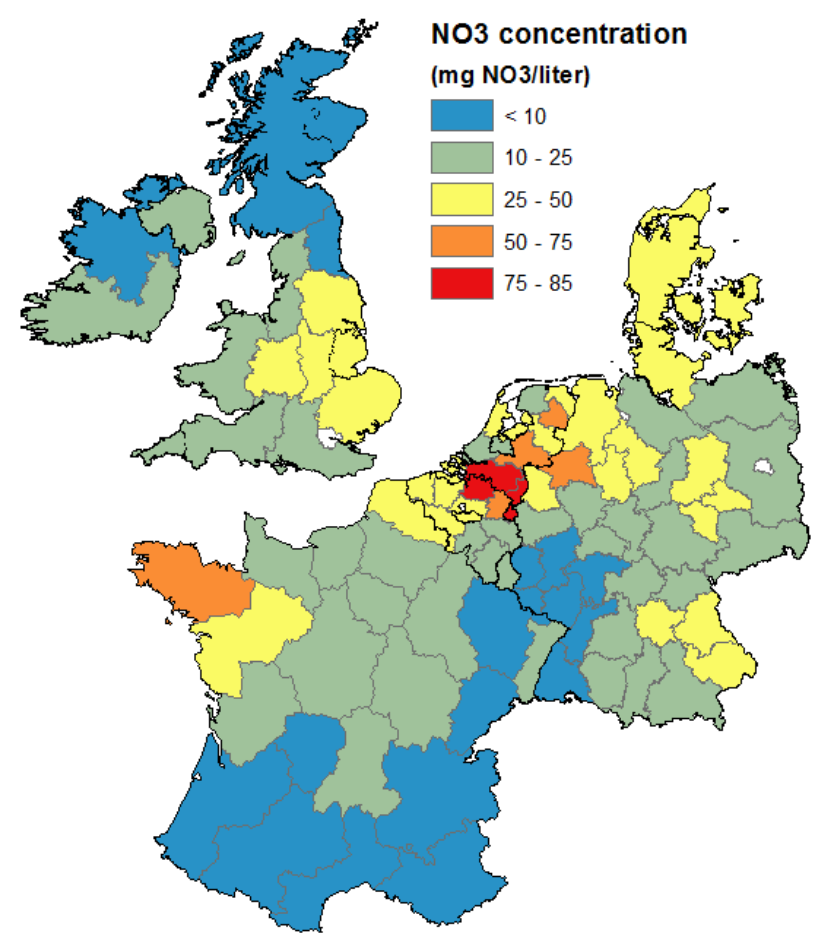

Fig. 7. Mean nitrate concentration in leaching water from the rootzone in 2008 at NUTS2 level by the MITERRA model.

\section{Discussion}

\subsection{Application standards}

The theoretical or empirical basis of differences between nitrogen application standards in national regulations for $\mathrm{NiD}$ implementation in northwest European countries is not always clear (Table 8). Differences between standards to a large extent derive from differences in fertilizer recommendation in the northwestern members states (Table 11). One may expect more comparable fertilizer recommendations in

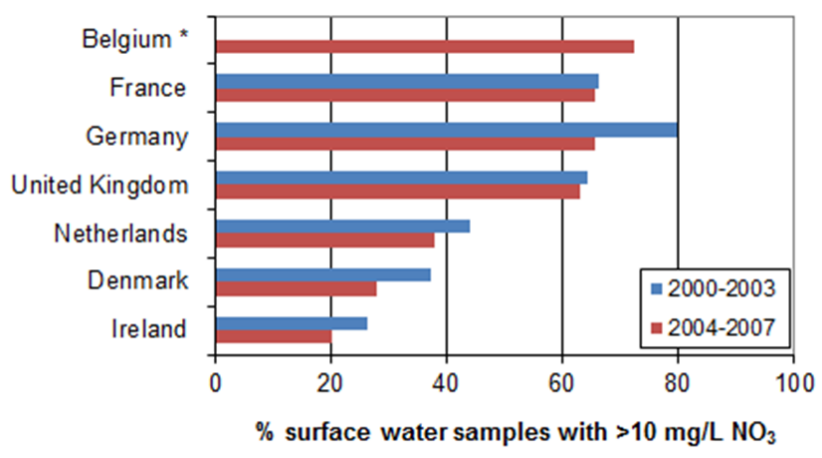

Fig. 8. Percentage of surface water samples in monitoring programs for the Nitrates Directive exceeding $10 \mathrm{mg} \mathrm{NO}_{3} \mathrm{~L}^{-1}$ for the 2 nd and 3rd reporting period (European Commission, 2011). $* \mathrm{NO}_{3}$ data for 2000-2003 were not available.

view of the similar yield potentials. However, it is difficult to compare fertilizer recommendations as different countries apply different systems (ten Berge and van Dijk, 2009). The Flemish Region, Denmark and the Netherlands use systems based on dose-effect trials, while Germany and France use a balance approach. All countries use calculation schemes to correct $\mathrm{N}$ recommendations for yield level and $\mathrm{N}$ deliveries from soil, and cropping history and manure application. These schemes are not standard, and may depend on the local advisors, which leads to significant variability in the recommendations. In general nitrogen application standards in $\mathrm{NiD}$ action programs for Denmark and for fodder maize on dry sandy soils in the Netherlands tend to be lower than the Nfertilizer recommendation. In the Danish case the legal application standards are now $10 \%$ under the economic optimum for all crops. With the recently introduced standards, this is partly also the case for the Flemish Region.

The overall effects of these differences on the $\mathrm{N}$ balance and on water quality are difficult to judge, as standards are implemented at farm level and crops are cultivated in rotations. Denmark has far less permanent grassland than the Netherlands and grassland contains more clover while temporary grassland is part of the crop rotation. Such differences in rotations to some extent may level out environmental effects of differences between standards for individual crops. A more elaborate analysis is needed to assess whether differences in recommendations between countries are justified in economic terms, and whether differences in application standards are justified from the environmental viewpoint. This is beyond the scope of our contribution.

\subsection{Nitrogen balance}

There are considerable differences between estimates of GNB in EUROSTAT, by MITERRA and in national reports (Table 12). Precise comparison of results for GNB was difficult because results were not always available for the same years and because data underlying GNB for a specific 
Table 11. Ranges of $\mathrm{N}$ recommendations in different regions for sandy to loamy soils with no effect of previous crop and a medium level of soil nitrogen supply (SNS). Relatively high N-recommendations are found in The Netherlands and Denmark, relatively low values in France and the UK (sources: Dijk and Berge, 2009; for FL Bodemkundige Dienst van België, 2012; for UK DEFRA, 2010 for FR COMIFER, 2011 ; for IRL Coulter and Lalor, 2008).

\begin{tabular}{llllllll}
\hline & NL & DK & FL & GE & FR & UK & IRL $^{1}$ \\
\hline & \multicolumn{7}{c}{$\mathrm{kg} \mathrm{Nha}^{-1}$} \\
\cline { 2 - 8 } Grass & $285-385$ & $365-405$ & $250-300$ & $200-300$ & $50-250^{2}$ & $180-340$ & $40-306^{2}$ \\
Fodder maize & $150-175$ & $160-190$ & $150-175$ & $150-160$ & $70-160$ & 50 & $110-180$ \\
Winter wheat & $190-230$ & $180-210$ & $150-190$ & $130-220$ & $10-210$ & $70-120$ & $120-210^{3}$ \\
Potato - ware & $245-250$ & $155-180$ & $200-225$ & $70-140$ & $100-160$ & $60-160$ & $120-170$ \\
Sugar beet & 150 & $125-150$ & $130-160$ & $90-150$ & $100-140$ & 80 & $120-195$ \\
\hline
\end{tabular}

\footnotetext{
${ }^{1}$ Rates shown for non-grassland correspond to a soil $\mathrm{N}$ Index range of 1 to 3.

${ }^{2}$ Rates of $\mathrm{N}$ application on grassland vary depending on stocking rate and usage for grazing and/or cutting.

${ }^{3}$ Assuming $9 \mathrm{tha}^{-1}$ yield of winter wheat (additional $\mathrm{N}$ is recommended for higher yields).
}

Table 12. Annual N removal, and gross $\mathrm{N}$ balance (GNB) by MITERRA in 2008, compared to values in Eurostat and national reports in the period 2004-2009.

\begin{tabular}{|c|c|c|c|c|c|c|c|}
\hline & \multicolumn{3}{|c|}{ MITERRA 2008} & \multicolumn{2}{|c|}{ EUROSTAT 2005-2008 } & \multicolumn{2}{|c|}{ National 2004-2009 } \\
\hline & UAA & removal & GNB & removal & GNB & removal & GNB \\
\hline & mln ha & \multicolumn{2}{|c|}{$\mathrm{kg} \mathrm{Nha}^{-1}$} & \multicolumn{2}{|c|}{$\mathrm{kgNha}^{-1}$} & \multicolumn{2}{|c|}{$\mathrm{kg} \mathrm{Nha}^{-1}$} \\
\hline EU27 & 172.5 & 67 & 70 & & & & \\
\hline Belgium & 1.4 & 149 & 156 & 191 & 118 & $191^{1}$ & $117^{1}$ \\
\hline Flemish $R$ & 0.7 & 166 & 200 & & & $\begin{array}{l}213-223^{2} \\
220^{1}\end{array}$ & $\begin{array}{l}57^{2} \\
63^{1}\end{array}$ \\
\hline Walloon $R$ & 0.7 & 135 & 122 & & & $163^{1}$ & $57^{1}$ \\
\hline Denmark & 2.5 & 106 & 82 & 101 & 93 & $115^{3}$ & $79^{3}$ \\
\hline France & 30.1 & 80 & 67 & 112 & 49 & $120^{4}$ & $50^{4}$ \\
\hline North. France & 17.8 & 87 & 79 & & & & \\
\hline Brittany & 1.6 & 89 & 215 & & & 138 & $79^{5}$ \\
\hline Germany & 16.7 & 122 & 81 & 125 & 92 & $131^{6}$ & $91^{6}$ \\
\hline Ireland & 4.1 & 132 & 108 & 155 & 50 & 155 & 53 \\
\hline Netherlands & 1.9 & 179 & 213 & 194 & 188 & $209^{7}$ & $178^{7}$ \\
\hline United Kingdom & 14.3 & 72 & 84 & 111 & 93 & $137^{8}$ & $91^{8}$ \\
\hline
\end{tabular}

${ }^{1}$ Gybels et al., 2009, for period 2004-2006.

2 Lenders et al., 2012, for period 2007-2009.

${ }^{3}$ Grant et al., 2010, period 2006-2008.

${ }^{4}$ Anonymous 2008a, period 2004-2006; GNB inferred from SNB using gaseous N loss by MITERRA.

${ }^{5}$ Agreste, 2012; mean for 2006, 2008 and 2012. SNB value converted to GNB using gaseous N loss by MITERRA ( $48 \mathrm{~kg} \mathrm{Nha}^{-1}$ ).

${ }_{7}^{6}$ Anonymous, 2008c, period 2004-2006.

${ }^{7}$ CBS statline, http://statline.cbs.nl, downloaded January 2012.

${ }^{8}$ Fernal and Murray, 2009, period 2005-2007.

year are regularly modified. GNB for 2008 calculated by MITERRA is on average $19 \mathrm{~kg} \mathrm{Nha}^{-1}$ higher than reported to the EU Commission (EUROSTAT) and to a lesser extent than reported by the OECD (Velthof et al., 2009). Differences are most marked for Belgium and Ireland. $\mathrm{N}$ removal and, to a lesser extent, $\mathrm{N}$ excretion (not shown) are major sources of difference between GNB estimates. National use of chemical fertilizer in general is fairly accurate, but values for specific years in national reports, e.g. Belgium, show quite some variation, and in part reflect the absence of reliable registration systems for fertilizer purchase. Different estimates of UAA play a minor role.

On average, estimates of $\mathrm{N}$ removal in MITERRA (2008) for the seven member states are $22 \mathrm{~kg} \mathrm{~N}^{-1}$ lower than estimates for EUROSTAT (2005-2008) and could fully account for the mean difference of GNB (Table 12). Estimates in national reports for some countries tend to be somewhat higher than values reported to EUROSTAT, but this in part may be due to comparing different periods. The uncertainty of $\mathrm{N}$ removal in crops is further illustrated by results from Leip et 
al. (2008), that were on average nearly $28 \mathrm{~kg} \mathrm{~N} \mathrm{ha}^{-1}$ higher than in EUROSTAT, using a more deterministic European model approach. $\mathrm{N}$ removal from grassland for fodder likely is the major source of difference in estimates of total $\mathrm{N}$ removal (Velthof et al., 2009). MITERRA excretion (2008) on average is $7 \mathrm{~kg} \mathrm{Nha}^{-1}$ higher than in EUROSTAT (20052008).

For the Flemish Region Lenders et al. (2012) estimate N removal at about $320 \mathrm{~kg} \mathrm{~N} \mathrm{ha}^{-1}$ based on grassland yields of 10.5 ton $\mathrm{ha}^{-1}$ for permanent grassland and $11.5 \mathrm{ton} \mathrm{ha}^{-1}$ for temporary grassland, and an $\mathrm{N}$ content of $3 \%$. MITERRA estimates $\mathrm{N}$ removal from permanent grassland at about $220 \mathrm{~kg} \mathrm{~N} \mathrm{ha}^{-1}$. Differences are caused by lower estimates of effective dry matter yield for mixed system of grazing and cutting, and of lower $\mathrm{N}$ contents. Estimates of mean $\mathrm{N}$ removal from grassland in the Netherlands, with practices and $\mathrm{N}$ intensity comparable to that in the Flemish Region, are around $260 \mathrm{~kg} \mathrm{~N} \mathrm{ha}^{-1}$. So overestimation of $\mathrm{N}$ removal from grassland ( $36 \%$ of UAA) could explain a major part of the difference between GNB estimates by MITERRA and national reports.

GNB in 2008 by MITERRA for Brittany in France is more than twice the regional estimate for 2006-2010 (Agreste, 2012). Again this can be largely ( $>50 \%$ ) explained by a much higher regional estimate of $\mathrm{N}$ removal, and to lesser extent by lower estimates of manure input (about 20\%) and chemical fertilizer (about 10\%). Regional data would suggest an overall nitrogen use efficiency ( $\mathrm{N}$ removal over total $\mathrm{N}$ input from fertilizer and manures) of $80 \%$, which does not seem realistic. Nitrogen use efficiency in Brittany by MITERRA is about $40 \%$, as compared to $60 \%$ for EU27.

For Ireland, total $\mathrm{N}$ removal in MITERRA in 2008 is $23 \mathrm{~kg} \mathrm{Nha}^{-1}$ lower than the average $\mathrm{N}$ removal between 2005 and 2008 in EUROSTAT and national reports. In Ireland 3.9 mln ha of UAA $(95 \%)$ is grassland. Mean $\mathrm{N}$ removal on grassland is estimated for EUROSTAT at $155 \mathrm{~kg} \mathrm{Nha}^{-1}$, while MITERRA calculates about $130 \mathrm{~kg} \mathrm{~N} \mathrm{ha}^{-1}$. Part of this difference may be due to different assumptions on reduction of yields and $\mathrm{N}$ removal for grazing as compared to cutting, and to different assumptions on shares of intensively and extensively managed grassland. Differences in $\mathrm{N}$ removal per hectare between intensive and extensive grassland can amount to a factor of two (Velthof et al., 2009). Another major source of discrepancy for Ireland between MITERRA results and national reporting is a higher gross input of $\mathrm{N}$ in manure. In Ireland almost $90 \%$ of $\mathrm{N}$ production in manure is from cattle. Irish national reports use an $\mathrm{N}$ excretion value of $85 \mathrm{~kg} \mathrm{~N}$ per dairy cow (Anonymous, 2010), while MITERRA uses a value of $105 \mathrm{~kg} \mathrm{~N}$ per dairy cow (Velthof et al., 2011; Annex 1). The high value is based on a more dynamic approach accounting for regional differences in milk yields, grassland yields, and $\mathrm{N}$ inputs, while the low value is mainly a function of milk yield. Estimates of $\mathrm{N}$ removal for fodder and $\mathrm{N}$ excretion are related, as fodder is the major $\mathrm{N}$ input and manure $\mathrm{N}$ is the major output. For Ireland, $\mathrm{N}$ removal in
EUROSTAT (and national reports) is more than $30 \%$ higher than $\mathrm{N}$ excretion. Even when taking into account $\mathrm{N}$ removal in milk and meat and $\mathrm{N}$ imports of feed concentrates, the large difference between $\mathrm{N}$ removal and $\mathrm{N}$ excretion may be an indication that either $\mathrm{N}$ removal is overestimated or $\mathrm{N}$ excretion is underestimated. On the other hand, excretion estimates by MITERRA do not seem to match with a relatively modest average milk yield in Ireland around $5000 \mathrm{~kg}$ per cow per year.

Germany is the only country that has established targets for the surplus of $\mathrm{N}$ (90 kg ha-1 for 2006-2008) and phosphate $\left(20 \mathrm{~kg} \mathrm{ha}^{-1}\right.$ in a six-year average); and managed to achieve these targets in 2008. The stricter targets of $60 \mathrm{~kg} \mathrm{Nha}^{-1}$ as a three-year average from 2009-2011 onwards may also be achieved, but some intensive livestock farms and other farms with higher $\mathrm{N}$ surplus still have to increase their $\mathrm{N}$ efficiency. Infringements of these restrictions are not directly subject to fines, but will lead to administrative procedures with increasing obligations for farmers to adapt to the maximum surplus levels.

Recent national census data indicate that since 2008 the use of chemical fertilizer in Denmark, Germany and the Netherlands is still decreasing, and along with that, probably also the soil surplus of nitrogen. The decrease of the purchase of chemical $\mathrm{N}$ fertilizer coincides with the increase in fertilizer prices since 2008 (Fig. 9). This price increase is not compensated by an increase of prices of agricultural commodities. Between 1990 and 2011 the price of nitrogen fertilizer in Europe has increased twice as fast as the price of wheat, but since 2007 both prices have become very volatile. In view of the high fertilizer prices farmers may tend to reduce or postpone fertilizer purchases. The latter hypothesis is supported by a decrease of purchase of chemical $\mathrm{N}$ fertilizer in Germany in 2009 and 2010. In Denmark and the Netherlands the purchase of $\mathrm{N}$ fertilizer was hardly affected, which can be explained by the presence of legal $\mathrm{N}$ application standards that are below the economic optimum. So changes of nitrogen use and surpluses since 2008 in part can be price effects which interfere with effects of the NiD. This price effect is more apparent for the use of inorganic phosphate fertilizer which increased since 2009 in all three countries.

\subsection{Implications for the NiD}

Monitoring and evaluation of the implementation and effects of $\mathrm{NiD}$ is crucial for its success. At a national level it is a requirement to maintain support from farmers and their local advisors, as the main actors involved, and for national governments to optimize policies. The main activities for monitoring and evaluation are registrations of farm resources and activities (fertilizer, livestock, UAA), monitoring of water quality and using calculation procedures and models to assess environmental loads and relate this to farm measures and water quality. These evaluation activities take place at the national level, with varying levels of detail and sophistication, 
and in a more harmonized and generalized manner at the European level. For the latter, the European Commission uses institutes like the European Environment Agency (EEA) and the Joint Research Centers (JRC) and has initiated various service contracts, to improve datasets of agricultural activities, and develop and apply models to relate activities to $\mathrm{N}$ emissions and water quality (RAINS, GAINS, CAPRI, MITERRA). In spite of recent progress it is difficult to judge to what extent national implementation and evaluation of the $\mathrm{NiD}$ benefits from joint activities and what are major caveats in data and knowledge about the effects and effectiveness of the NiD.

A typical conclusion from national evaluations is that the $\mathrm{NiD}$ has made a major contribution to reduction of the $\mathrm{N}$ surplus. Evaluation of the Danish Aquatic Plan II concluded that between 1998 and 2004 the reduction of $\mathrm{N}$ application standards contributed $13 \mathrm{mln} \mathrm{kg} \mathrm{(32 \% )} \mathrm{to} \mathrm{the} \mathrm{total} \mathrm{reduction} \mathrm{of}$ the soil $\mathrm{N}$ surplus (SSNB) of $80 \mathrm{mln} \mathrm{kg}$, while increasing legal FE for $\mathrm{N}$ in manure contributed $10 \mathrm{mln} \mathrm{kg}(26 \%)$ and reduced $\mathrm{N}$ in feeding $4 \mathrm{mln} \mathrm{kg} \mathrm{(10 \% )} \mathrm{(Mikkelsen} \mathrm{et} \mathrm{al.,} \mathrm{2010).}$ Evaluation of the Dutch second action program concluded that between 1998 and 2004 the Mineral Accounting System (MINAS) led to an overall reduction of the net SSNB by 78 mln kg N (van Grinsven et al., 2005). Here the combination of reducing $\mathrm{N}$-loss standards, and more efficient $\mathrm{N}$ management by better insight from keeping mineral accounts at farm level, contributed about $100 \mathrm{mln} \mathrm{kg}(67 \%)$, while reduced $\mathrm{N}$ in feeding contributed $14 \mathrm{mln} \mathrm{kg}(19 \%)$ and reducing livestock and increasing manure export $11 \mathrm{mln} \mathrm{kg}(14 \%)$. In the Netherlands the dairy sector contributed most to reduction of the use of chemical fertilizer, and this reduction was both a learning effect of applying mineral accountancy at farm level and of enforcement of N-loss standards.

In spite of various efforts at the European level to streamline procedures for monitoring and evaluation of the NiD, implementation and insight into the effectiveness still vary considerably. A first logical step is to further harmonize procedures for monitoring water quality and for assessing the nitrogen balance, while recognizing country specific monitoring needs to, for example, show the effectiveness of specific measures in an Action Program (Fraters et al., 2011). Another major source of difference among member states is how manure $\mathrm{N}$ is taken into account in recommendations as well as in the regulation of allowable $\mathrm{N}$ input. Nitrogen emissions from agricultural sources, particularly manures, are a major source of environmental pollution and welfare loss (Sutton et al., 2011). A logical next step for improving harmonization and effectiveness of the NiD is to demand stricter accounting of nitrogen in manures, e.g. by imposing a compulsory time path for increasing nitrogen fertilizer equivalencies for different types of manures in application limits (Csathó and Radimszky, 2009). However, such steps require knowledge sharing, e.g. in defining codes of Good Agricultural Practice and adopting techniques to improve nitrogen efficiency in manures. Without that, a too fast and too strict regulation of

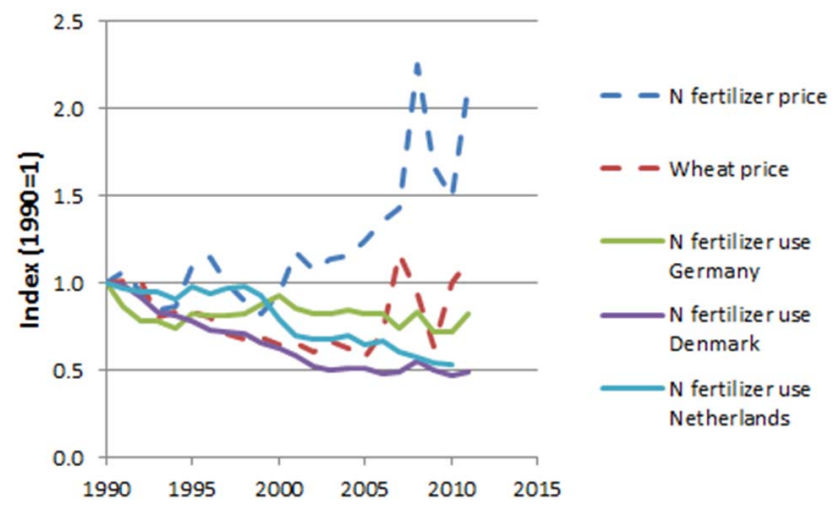

Fig. 9. Trends since 1990 of prices of nitrogen fertilizer and of wheat in the EU, and trends of total use of inorganic nitrogen fertilizer in agriculture in Germany (http://www.bmelv-statistik.de; N fertilizer use in 1990 was $130 \mathrm{~kg} \mathrm{Nha}^{-1}$ ), Denmark (http://www. statbank.dk/; $\mathrm{N}$ fertilizer use in 1990 was $150 \mathrm{~kg} \mathrm{Nha}^{-1}$ ) and the Netherlands (http://statline.cbs.nl/StatWeb/; N fertilizer use in 1990 was $220 \mathrm{~kg} \mathrm{~N} \mathrm{ha}^{-1}$ ) (downloaded 31 October 2012). Note: the MacSharry reform in 1992 and later reforms reduced the price support for cereals and therefore also the price of wheat.

nitrogen in manures may decrease the willingness of arable farmers to accept manure from livestock farmers, because of fear of insufficient $\mathrm{N}$ supply. In the future, increasing prices of nitrogen fertilizer may provide an additional economic incentive to reduce the use of chemical fertilizer and to increase the efficiency of manures.

The NiD and the national implementation of restrictions on where, when and how much nitrogen in fertilizer and manure can be applied to agricultural land, will remain a major instrument to reduce nitrogen pollution in waters. However, we should also recognize that agricultural sources of nitrate are only part of the nitrogen burden. In 2005, diffuse agricultural sources in the EU on average contributed $55 \%$ to the $\mathrm{N}$ load to surface waters, the remainder coming from communal, industrial and natural sources. The agricultural shares for northwest European countries tend to be higher, ranging from 50 to $60 \%$ in the UK, Germany, France and Belgium to $70-85 \%$ in the Netherlands, Denmark and Ireland (inferred from Bouraoui et al., 2011). So even when all the measures under NiD have taken hold, it is unlikely that nitrate concentrations in surface water, and to a lesser extent in groundwater, will return to pre-industrial levels (Howden et al., 2011). For the immediate future the importance of the $\mathrm{NiD}$ for protecting drinking water may be best seen in those areas with private or small public drinking water facilities, using groundwater from shallow aquifers, as is the case in Denmark (van Grinsven et al., 2010). In order to protect their coastal waters, member states in deltas or estuaries of large cross boundary rivers, like the Netherlands and Romania, depend on the NiD, particularly when national implementation of the Water Framework Directive is limited to reducing nonagricultural sources of $\mathrm{N}$. A problem when implementing the 
$\mathrm{NiD}$ for this purpose is that the limit value of $50 \mathrm{mg} \mathrm{L}^{-1}$ does not apply to fresh waters and coastal waters (Nimmo Smith et al., 2007). Nonetheless, the NiD requires member states to protect such bodies at risk of eutrophication. The lack of a single standard along with the range of influences that bear on eutrophication can cause some confusion. For control of coastal eutrophication, e.g. in Brittany, a limit value around 5-10 $\mathrm{mg} \mathrm{NO}_{3} \mathrm{~L}^{-1}$ would be more appropriate.

\section{Conclusions}

The most significant effect of the implementation of the NiD since 1995 in the northwest of the EU is a major contribution to the decrease of the nitrogen soil $\mathrm{N}$ balance and by that of the gross $\mathrm{N}$ load to the aquatic environment. This effect of the NiD has not yet manifested in a convincing decrease of nitrate concentrations in EU monitoring in groundwater and fresh surface waters since 2000. However, before 2000, introduction of Good Agricultural Practices for fertilization has decreased median and extreme nitrate concentration in many surface water systems in e.g. the Netherlands, Denmark and the Flemish Region. Only countries that operate long running monitoring programs in shallow groundwater in agricultural areas, viz. Denmark and the Netherlands, can detect a convincing decrease of nitrate concentrations.

Without good opportunities to evaluate the effectiveness of NiD, it is difficult for the EU community to improve the $\mathrm{NiD}$ and implementation in member states may lose momentum. This benchmark study indicates that differences in calculation and data procedures between member states in northwestern EU for determining the nitrogen balances are such that comparison of effects of $\mathrm{NiD}$ on the $\mathrm{N}$ balance between countries is not yet possible. In particular the calculations methods for $\mathrm{N}$ excretion and $\mathrm{N}$ removal vary considerably among countries. Regarding compliance with application limit for $\mathrm{N}$ in manure also the definition of farm area differs between countries ranging from total farm area to the area where manure actually is applied. Harmonization of the rationale of national fertilizer recommendation systems is important for deriving $\mathrm{N}$ application standards that can lead to balanced fertilization, as required by the $\mathrm{NiD}$, and eventually to create a transparent policy debate about balancing economic and environmental goals across the EU. Improved guidelines and procedures for monitoring water quality and registration of fertilizer use also would improve the evaluability of the NiD. Better selections of, and access to the collective monitoring results in EU synthesis reports and data facilities can help to improve the efficiency of our monitoring effort to evaluate the NiD.

Implementation of the NiD in member states in the northwest of the EU is fairly comparable regarding restrictions for application of fertilizer and manure, but can be quite different regarding application standards for total $\mathrm{N}$ fertilization. Nitrogen application standards in national implementations of the NiD are closely linked to national nitrogen fertilizer recommendations. However, differences in national systems for nitrogen recommendations are substantial and resulting recommendations for specific combination of crops and soils and do not bear a clear relationship with differences in yield per hectare.

At some point in the future, when the first and relatively easy environmental improvements by the present implementations of NiD are achieved, the NiD may need adjustment to become more effective, notably through more specific regulation of nitrogen in manure and through differentiation of targets with respect to water quality. This will also help to achieve the targets set in the Water Frame Work Directive. However, there is an immediate need to improve our data procedures to allow evaluation and benchmarking of adequacy and effectiveness of NiD implementation.

Edited by: S. Reis

\section{References}

Agreste: Bilan azote et phosphore - Résultats 2010, Ministère de l'agriculture, Direction Régionale de l'agroalimentaire et de la forêt de Bretagne, Service de Statistique Agricole (Agreste), available at: http://draf.bretagne.agriculture.gouv.fr/ IMG/pdf/44-45_azote_phosphore_cle4b161d.pdf, 2012.

Anonymous: Bilan de la mise en oevre de la Directive Nitrates en France (2004-2007), Ministère de l' Écologie, de l' Énergie, du Développement Durable et de l'Amenagement du Territoire, 2008a.

Anonymous: Directive Nitrates (91/676), Rapport vise a l'articele 10, Partie I, Bilan et evolution de la qualité des eaux et des pratiques agricoles en Région Wallonne, Ministère de la Région Wallonne, Direction Génerale des Ressources Naturelles en de l'Environnement, 2008b.

Anonymous: Article 10 Nitrates Report 91/676/EEC Nitrates Report for Ireland 2004-2007, 2008c.

Anonymous: Bericht gemäß Artikel 10 der Richtlinie 91/676/EWG des Rates vom 12 Dezember 1991 zum Schutz der Gewässer vor Verunreinigungen durch Nitrat aus landwirtschaftlichen Quellen, Mitteilung der Regierung der Bundesrepublik Deutschland, 2008d.

Anonymous: Status and trends of aquatic environment and agricultural practice, Danish monitoring and action programmes in accordance with the Nitrates Directive (1991/676/EEC), Preliminary Summary Report to the European Commission, Danish Environmental Protection Agency, 2008e.

Anonymous: Statutory Instrument S.I. No. 610 of 2010, Stationary Office, Dublin, Ireland, 2010.

Anonymous: Normen en richtwaarden, Vlaamse Landmaatschappij, 2011.

Bodemkundige Dienst van België: Wegwijs in de bodemvruchtbaarheid van de Belgische akkerbouw- en weilandpercelen (2008-2011), Heverlee, Belgium, 2012.

Bouraoui, F., Grizzetti, B., and Aloe, A.: Long term nutrient loads entering European seas, European Commission Joint Research 
Centre, Institute for Environment and Sustainability, Ispra, Italy, 2011.

Cardoso, A. C., Duchemin, J., Magoarou, P., and Premazzi, G.: Criteria for the identification of freshwaters subject to eutrophication: their use for the implementation of the Nitrates and Urban Waste Water treatment Directives, EUR Report 19810 EN, European Commission Joint Research Centre, Luxembourg, 2001.

COMIFER: Calcul de la fertilisation azotée: guide méthodologique pour l'établissement des prescriptions locales, cultures annuelles et prairies Edn. 2011, available at: http://www.comifer.asso.fr/ images/stories/pdf/brochureazotemajmars\%202012.pdf, 2011.

Coulter, B. S. and Lalor, S. (Eds.): Major and micro nutrient advice for productive agricultural crops, 3rd Ed., Teagasc, Johnstown Castle, Wexford, 2008.

Csatho, P. and Radimszky, L.: Two Worlds within EU27: Sharp Contrasts in Organic and Mineral Nitrogen-Phosphorus Use, Nitrogen-Phosphorus Balances, and Soil Phosphorus Status: Widening and Deepening Gap between Western and Central Europe, Comm. Soil Sci. Plant Anal. 40, 999-1019, 2009.

Dalgaard, T., Olesen, J. E., Petersen, S. O., Petersen, B. M., Jørgensen, U., Kristensen, T., Hutchings, N. J., Gyldenkærne, S., and Hermansen, J. E.: Developments in greenhouse gas emissions and net energy use in Danish agriculture - How to achieve substantial $\mathrm{CO}_{2}$ reductions?, Environ. Pollut., 159, 3193-3203, 2011.

Dalgaard, T., Bienkowski, J. F., Bleeker, A., Drouet, J. L., Durand, P., Dragosits, U., Frumau, A., Hutchings, N. J., Kedziora, A., Magliulo, V., Olesen, J. E., Theobald, M. R., Maury, O., Akkal, N., and Cellier, P.: Farm nitrogen balances in six European agricultural landscapes - a method for farming system assessment, emission hotspot identification, and mitigation measure evaluation, Biogeosciences Discuss., 9, 8859-8904, doi:10.5194/bgd9-8859-2012, 2012.

De Clercq, P., Gertsis, A. C., Hofman G., Jarvis, S. C., Neeteson, J. J., and Sinabell, F. (Eds.): Nutrient Management Legislation in European Countries, Wageningen Press, The Netherlands, 2001.

de Vries, W., Leip, A., Reinds, G. J., Kros, J., Lesschen, J. P., and Bouwman, A. F.: Comparison of land nitrogen budgets for European agriculture by various modeling approaches, Environ. Pollut., 159, 3254-3268, 2011.

DEFRA: Fertiliser Manual (RB209), 8th Edition, United Kingdom, 2010.

Desimpelaere, K., Lesage, E., Eppinge, r R., and Van Hoof, K.: Vierjaarlijks verslag in het kader van de Nitraatrichtlijn (91/676/EEG) voor het Vlaams Gewest, Vlaamse Landmaatschappij en Vlaams Milieumaatschappij, 2008.

EFMA: Forecast of food, farming and fertilizer use in the European Union 2008-2018. European Fertilizer Manufacturers Association (now Fertilizers Europe), Volume 1, Executive summary and regional data, 2008.

EMEP: EMEP Measurement Database. The Co-operative Programme for the Monitoring and Evaluation of the Long-Range Transmission of Air Pollutants in Europe, http://www.emep.int/, 2010.

European Commission: Report from the commission to the Council and the European Parliament on implementation of the Council Directive 91/676/EEC concerning the protection of water against pollution caused by nitrates from agricultural sources for the period 2000-2003 SEC(2007)339/COM/2007/0120 final, Brussels,
2007.

European Commission: Report from the commission to the Council and the European Parliament on implementation of the Council Directive 91/676/EEC concerning the protection of water against pollution caused by nitrates from agricultural sources for the period 2004-2007 SEC(2010)118, COM(2007)47 final/2, Brussels, 2011.

Eurostat, Pocketbook: Food from farm to fork, 2011.

Eurostat, Nitrogen balance in agriculture (data September 2011), http://epp.eurostat.ec.europa.eu/statistics_explained/index.php/ Nitrogen_balance_in_agriculture, 17 January, 2012.

Fenton, O., Richards, K. G., Kirwan, L., Khalil, M. I., and Healy, M. G.: Factors affecting nitrate distribution in shallow groundwater under a beef farm in South Eastern Ireland, J. Environ. Manage., 90, 3135-3146, 2009.

Fenton, O., Schulte, R. P. O., Jordan, P., Lalor, S. T. J., and Richards, K. G.: Lag time: a methodology for the estimation of vertical and horizontal travel \& flushing timescales to nitrate threshold concentrations in Irish aquifers, Environ. Sci. Policy, 14, 419431, 2011.

Fernal, D. and Murray, A.: UK TAPAS Action Soil Nutrient Balances Final Report, DEFRA, 2009.

Fraters, D., Kovar, K., Grant, R., Thorling, L., and Reijs, J. W.: Developments in monitoring the effectiveness of the EU Nitrates Directive Action Programmes, Bilthoven National Institute of Public Health and Environment, 2011.

Grant, R., Blicher-Mathiesen, G., Jensen, P.G., Hansen, B., and Thorling, L.: Catchment monitoring 2009 - NOVANA, National Environmental Research Institute (NERI) \& Geological Survey for Denmark and Greenland (GEUS), NERI report nr. 802, 2010.

Gybels, K., Wustenberghs, H., Claeys, D. Verhaegen, E., Lauwers, L., and Kestemont, B.: Nutrient Balance for Nitrogen, Eurostat Grant Agreement 67101.2006.001-2007.093, Working paper no 22, Statistics Belgium, 2009.

Hansen, B., Thorling, L., Dalgaard, T., and Erlandsen, M.: Trend reversal of nitrate in Danish groundwater, a reflection of agricultural practices and nitrogen surpluses since 1950, Environ. Sci. Technol., 45, 228-234, 2011.

Hansen, B., Dalgaard, T., Thorling, L., Sørensen, B., and Erlandsen, M.: Regional analysis of groundwater nitrate concentrations and trends in Denmark in regard to agricultural influence, Biogeosciences, 9, 3277-3286, doi:10.5194/bg-9-3277-2012, 2012.

Hoekstra, N. J., Lalor, S., Richards, K. G., O'Hea, N., Dungait, J., Schulte, R. P. O., and Schmidt, O.: The fate of slurry N fractions in herbage and soil during two growing seasons following application, Plant Soil, 342, 83-96, 2011.

Howden, N. J. K., Burt, T. P. Worrall, F., Whelan, M. J., and Bieroza, M.: Nitrate concentrations and fluxes in the river Thames over 140 years (1868-2008): are increases irreversible?, Hydrol. Process., 24, 2657-2662, 2010.

Klimont, Z. and Brink, C.: Modelling of Emissions of Air Pollutants and Greenhouse Gases from Agricultural Sources in Europe, IIASA IR 04-048, Laxenburg, Austria, 2004.

Kronvang, B., Andersen, H. E., Børgesen, C., Dalgaard, T., Larsen, S. E., Bøgestrand, J., and Blicher-Mathiasen, G.: Effects of policy measures implemented in Denmark on nitrogen pollution of the aquatic environment, Environ. Sci. Policy, 11, 144-152, 2008 . 
Leip, A., Marchi, G., Koeble, R., Kempen, M., Britz, W., and $\mathrm{Li}$, C.: Linking an economic model for European agriculture with a mechanistic model to estimate nitrogen and carbon losses from arable soils in Europe, Biogeosciences, 5, 73-94, doi:10.5194/bg-5-73-2008, 2008.

Lenders S., D'hooghe J., and Overloop S.: Bodembalans van de Vlaamse landbouw, cijfers voor 2007-2009, Departement Landbouw en Visserij and Vlaamse Milieumaatschappij, Brussel, 2012.

Lerner, D.: Guidelines for estimating urban loads of nitrogen to groundwater, Defra project report NT 1845, 2000.

Lesschen, J. P., Witzke, H. P., Berg, M. van den, Westhoek, H., and Oenema, O.: Greenhouse gas emission profiles of the European livestock sectors, Anim. Feed Sci.Tech., 166-167, 16-28, 2011.

Lord, E. and Anthony, S.: MAGPIE: a modelling framework for evaluating nitrate losses at national and catchment scales, Soil Use Manage., 16, 167-174, 2000.

Mikkelsen, S. A., Iversen, T. M., Jacobsen, B. H., and Kjoer, S. S.: Reducing nutrient losses from intensive livestock operations, in: Livestock in a changing landscape, experiences and regional perspectives, edited by: Gerber, P., Mooney, H. A., Dijkman, J., Tarawal, S., and De Haan, C., Island Press, Washington, 140$153,2010$.

Nimmo Smith, R. J., Glegg, G. A., Parkinson, R., and Richards, J. P.: Evaluating the Implementation of the Nitrates Directive in Denmark and England using an Actor-Orientated Approach, Eur. Env., 17, 124-144, 2007.

OECD: OECD and EUROSTAT Gross nitrogen balances handbook, 2007.

Oenema, O.: Governmental policies and measures regulating nitrogen and phosphorus from animal manure in European agriculture, J Anim. Sci., 82, 196-206, 2004.

Panten, K., Rogasik, J., Godlinski, F., Funder, U., Greef, J.-M., and Schnug, E.: Gross soil surface nutrient balances: The OECD approach implemented under German conditions, Agr. Forest. Res., 1, 19-28, 2009.

Schröder, J. J., Scholefield, D., Cabral, F., and Hofman, G.: The effects of nutrient losses from agriculture on ground and surface water quality: the position of science in developing indicators for regulation, Environ. Sci. Policy, 7, 15-23, 2004.

Sutton, M. A., Oenema, O., Erisman, J. W., Leip, A., Grinsven, H. van, and Winiwarter, W.: Too much of a good thing, Nature, 472, 159-161, 2011.

ten Berge, H. and van Dijk, W.: Management of nitrogen inputs on farm within the EU regulatory framework, International Fertilizer Society - Publication Proceedings Proceeding 654, available at: http://www.fertiliser-society.org/Content/ Publications.asp, 2009.

Tiktak, A., Boesten, J. J. T. I., van der Linden, A. M. A., and Vanclooster, M.: Mapping groundwater vulnerability to pesticide leaching with a process-based metamodel of EuroPEARL, J. Environ. Qual., 35, 1213-1226, 2006. van Dijk, W. and ten Berge, H.: Agricultural nitrogen use in selected EU countries: a comparison of $\mathrm{N}$ recommendation, and restriction in response to the EU Nitrates Directive, Wageningen Plant Research International B.V., 2009.

van Grinsven, H., Eerdt, M., van, Willems, J., Hubeek, F., and Mulleneers, E.: Evaluation of the Dutch manure and fertilizer policy, 1998-2002, in: Evaluating Agri-Environmental Policies: Design, Practice and Results, 398-410, ISBN 92-6401010-6, OECD, 2005.

van Grinsven, H., Rabl, A., and de Kok, T. M.: Estimation of incidence and social cost of colon cancer due to nitrate in drinking water in the EU: a tentative cost-benefit assessment costbenefit assessment, Environ. Health, 9, doi:10.1186/1476-069X9-58, 2010.

Velthof, G. L., Oudendag, D., Witzke, H. P., Asman, W. A. H., Klimont, Z., and Oenema, O.: Integrated assessment of nitrogen losses from agriculture in EU-27 using MITERRA, J. Environ. Qual., 38, 402-417, 2009.

Velthof, G. L., Lesschen, J. P., Webb, J., Pietrzak, S., Miatkowski, Z., Kros, J., Pinto, M., and Oenema, O.: The impact of the Nitrates Directive on gaseous $\mathrm{N}$ emissions Effects of measures in nitrates action programme on gaseous $\mathrm{N}$ emissions, Contract ENV.B.1/ETU/2010/0009 http://ec.europa.eu/environment/water/water-nitrates/pdf/ Final_report_impact_Nitrates_Directive_def.pdf, 2012.

Wang, L.,Stuart, M. E., Bloomfield, J. P., Butcher, A. S., Gooddy, D. C., McKenzie, A., Lewis, M. A., and Williams, A. T.: Prediction of the arrival of peak nitrate concentrations at the water table at the regional scale in Great Britain, Hydrol. Process., 26, 226239, 2012.

Webb, J., Sørensen, P., Velthof, G., Amon, B., Pinto, M., Rodhe, L., Salomon, E., Hutchings, N., Burczyk, P., Menzi, H., and Reid, J. L.: Assessment of the variation of manure $\mathrm{N}$ efficiency throughout Europe and an appraisal of means to increase manure $\mathrm{N}$ efficiency, Adv. Agron., accepted, 2013.

Wolter, R., Osterburg, B., and Tetzlaff, B.: Developments in monitoring the effectiveness of the EU Nitrates Directive Action Programmes: Approach by Germany, in: Developments in monitoring the effectiveness of the EU Nitrates Directive Action Programmes, edited by: Fraters, B., Kovar, K., Grant, R., Thorling, L., and Reijs, J. W., Bilthoven, National Institute of Public Health and Environment, 211-256, 2011.

Zwart, M. H., Hooijboer, A. E. J., Fraters, B., Kotte, M., Duin, R. N. M., Daatselaar, C. H. G., Olsthoorn, C. S. M., and Bosma, J. N.: Agricultural practice and water quality in The Netherlands in the 1992-2006 period, National Institute for Public Health and the Environment, Bilthoven, 2008. 